\title{
Facemask Global Challenges: The Case of Effective Synthesis, Utilization, and Environmental Sustainability
}

\author{
Kamyar Shirvanimoghaddam ${ }^{1, *}$, Bożena Czech ${ }^{2} \mathbb{D}, \operatorname{Ram}_{\text {Yadav }}{ }^{1} \mathbb{D}$, Cemile Gokce $^{3}$, Laura Fusco ${ }^{4}$, \\ Lucia Gemma Delogu ${ }^{4}$, Açelya Yilmazer ${ }^{3,5}$, Graham Brodie ${ }^{6} \mathbb{D}^{D}$, Amani Al-Othman ${ }^{7}$ (D) Adil K. Al-Tamimi ${ }^{8}(\mathbb{D}$, \\ Jarret Grout ${ }^{1}$ and Minoo Naebe ${ }^{1, *}$
}

Citation: Shirvanimoghaddam, K.; Czech, B.; Yadav, R.; Gokce, C.;

Fusco, L.; Delogu, L.G.; Yilmazer, A.; Brodie, G.; Al-Othman, A.; Al-Tamimi, A.K.; et al. Facemask Global Challenges: The Case of Effective Synthesis, Utilization, and Environmental Sustainability. Sustainability 2022, 14, 737. https:// doi.org/10.3390/su14020737

Academic Editor: Elena Cristina Rada

Received: 10 November 2021 Accepted: 27 December 2021 Published: 10 January 2022

Publisher's Note: MDPI stays neutral with regard to jurisdictional claims in published maps and institutional affiliations.

Copyright: (C) 2022 by the authors. Licensee MDPI, Basel, Switzerland. This article is an open access article distributed under the terms and conditions of the Creative Commons Attribution (CC BY) license (https:// creativecommons.org/licenses/by/ $4.0 /)$.
1 Carbon Nexus, Institute for Frontier Materials, Deakin University, Waurn Ponds, Geelong 3216, Australia; r.yadav@deakin.edu.au (R.Y.); jarret.grout@deakin.edu.au (J.G.)

2 Department of Radiochemistry and Environmental Chemistry, Institute of Chemical Sciences, Faculty of Chemistry, Maria Curie-Sklodowska University in Lublin, 20-031 Lublin, Poland; bczech@hektor.umcs.lublin.pl

3 Department of Biomedical Engineering, Ankara University, Golbasi 06830, Turkey; cemile.gokce@ankara.edu.tr (C.G.); Acelya.Yilmazer.Aktuna@ankara.edu.tr (A.Y.)

4 Department of Biomedical Sciences, University of Padua, 35122 Padua, Italy; laura.fusco@unipd.it (L.F.); luciagemma.delogu@unipd.it (L.G.D.)

5 Stem Cell Institute, Ankara University, Balgat 06520, Turkey

6 School of Agriculture and Food, Faculty of Veterinary and Agricultural Science, The University of Melbourne, Melbourne 3010, Australia; grahamb@unimelb.edu.au

7 Department of Chemical Engineering, American University of Sharjah, Sharjah P.O. Box 26666, United Arab Emirates; aalothman@aus.edu

8 Civil Engineering Department, American University of Sharjah, Sharjah P.O. Box 26666, United Arab Emirates; atamimi@aus.edu

* Correspondence: kamyar.shirvanimoghaddam@deakin.edu.au (K.S.); minoo.naebe@deakin.edu.au (M.N.)

Abstract: Coronavirus disease (COVID-19), caused by the severe acute respiratory syndrome coronavirus 2 (SARS-CoV-2), has caused a rapidly spreading pandemic and is severely threatening public health globally. The human-to-human transmission route of SARS-CoV-2 is now well established. The reported clinical observations and symptoms of this infection in humans appear in the range between being asymptomatic and severe pneumonia. The virus can be transmitted through aerosols and droplets that are released into the air by a carrier, especially when the person coughs, sneezes, or talks forcefully in a closed environment. As the disease progresses, the use and handling of contaminated personal protective equipment and facemasks have become major issues with significant environmental risks. Therefore, providing an effective method for treating used/contaminated facemasks is crucial. In this paper, we review the environmental challenges and risks associated with the surge in facemask production. We also discuss facemasks and their materials as sources of microplastics and how disposal procedures can potentially lead to the contamination of water resources. We herein review the potential of developing nanomaterial-based antiviral and self-cleaning facemasks. This review discusses these challenges and concludes that the use of sustainable and alternative facemask materials is a promising and viable solution. In this context, it has become essential to address the emerging challenges by developing a new class of facemasks that are effective against the virus, while being biodegradable and sustainable. This paper represents the potentials of natural and/or biodegradable polymers for manufacturing facemasks, such as wood-based polymers, chitosan, and other biodegradable synthetic polymers for achieving sustainability goals during and after pandemics.

Keywords: COVID-19; facemasks; sustainability; biodegradable materials; facemask disposal 


\section{Introduction}

The recent outbreak of coronavirus has caused 5,320,000 fatalities, with a total of 271 million cases worldwide as of December 2021 [1]. This coronavirus is specifically referred to as severe acute respiratory syndrome coronavirus 2 (SARS-CoV-2) and is now widely known as the novel coronavirus, COVID-19 [2]. The study of biological properties of SARS-CoV-2 has revealed that it is an enveloped virus with single-stranded RNA. The shape of the virus can vary from spherical to oval, or pleomorphic morphology, as illustrated in Figure 1 [3]. SARS-CoV-2 infection is facilitated via the engagement of the virus spike with angiotensin converting enzyme 2 (ACE2) receptors followed by fusion between the viral envelope and the targeted host cell membrane [4]. The infection life cycle of SARS-CoV-2 underscores the importance of the development of targeted diagnostics for the disease [5] (as seen in Figure 2).

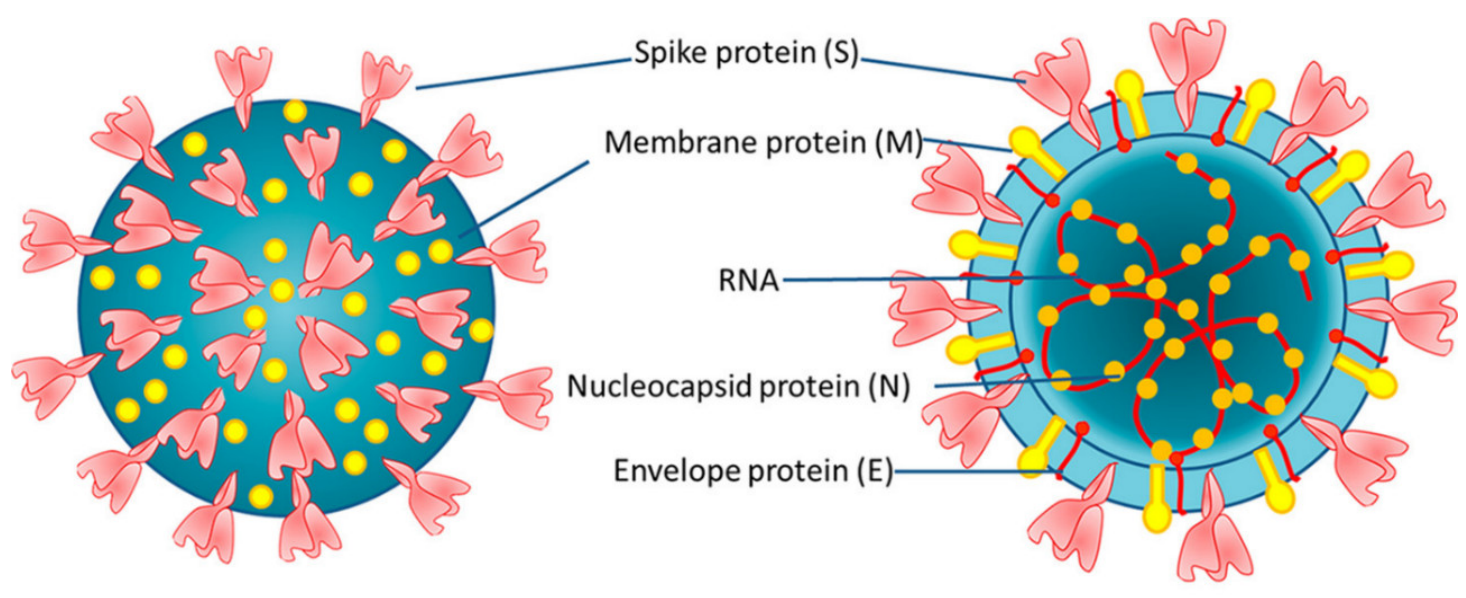

Outer section

Cross-section

Figure 1. Schematic representing the structure and morphology of SARS-CoV-2 [3].

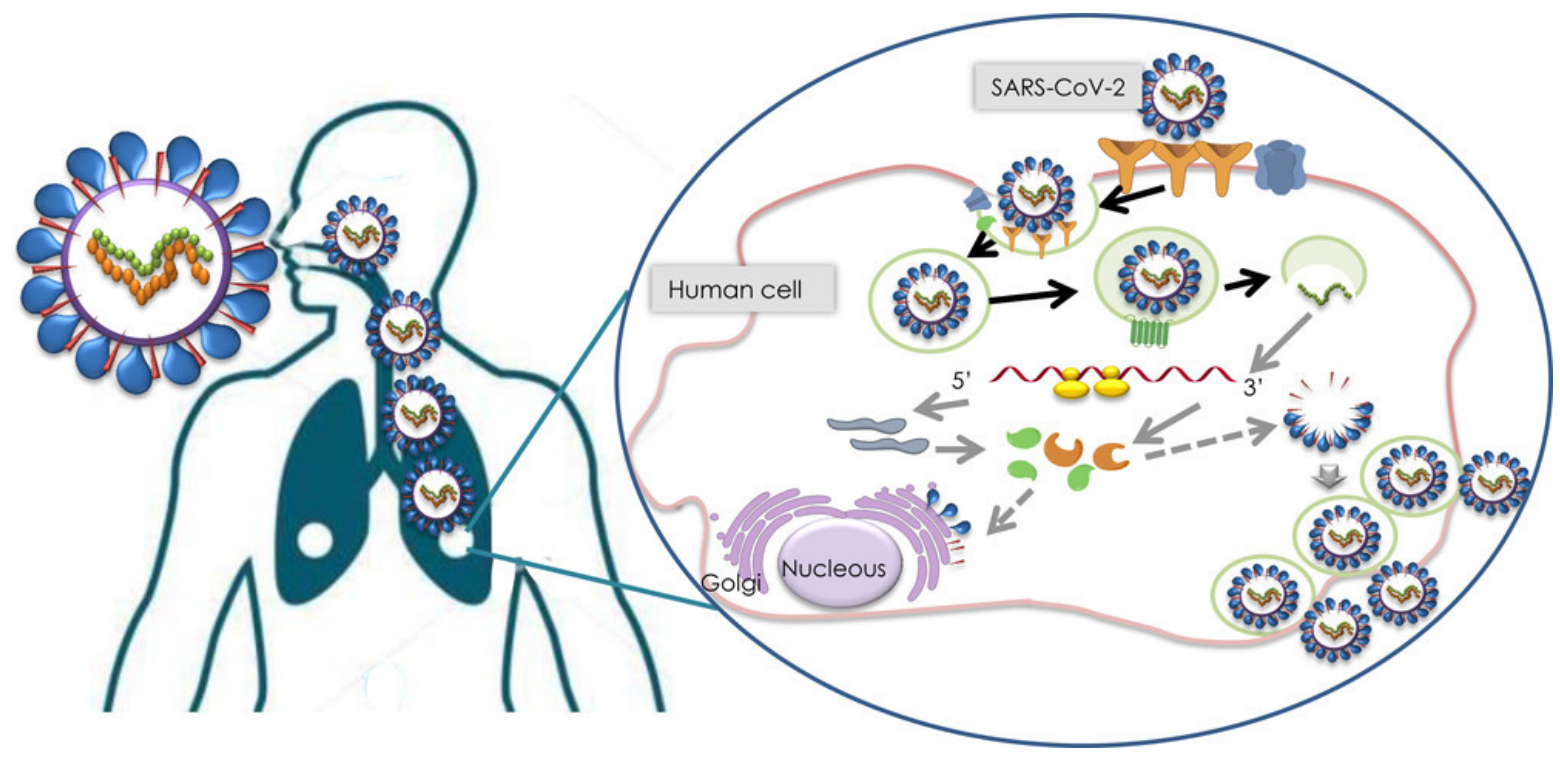

Figure 2. SARS-CoV-2 infection cycle [5].

The World Health Organization (WHO) has encouraged multiple measures, including face coverings, personal hygiene, and social distancing, as well as the use of personal protection equipment (PPE) for health workers and essential service providers [6]. 
In this context, facemasks have become the front line for protection against the spread of coronavirus worldwide. Although there is evidence to show the effectiveness of facemasks to stop the spread of viruses, their type and related efficacy are still under investigation in the context of pandemic viruses. Additionally, most facemasks are developed from polymer-based materials such as polypropylene, polystyrene, polyester, polyethylene, etc., which are not biodegradable [7]. The improper utilization and disposal of such non-biodegradable polymer-based facemasks are concerns among public health experts. Therefore, it has become essential to develop a class of biodegradable facemasks and to understand their effective filtration efficiencies and working mechanisms. It is also crucial to investigate the environmental impact of abandoned facemasks in the generation of micro and nanoplastics. Moreover, there is a need to consider the interaction of viruses and bacteria in abandoned facemasks with the hazardous materials in wastewater. In this paper, we review the environmental challenges and risks associated with the surge in facemask production. Hence, the objective of this paper is to crucially discuss solutions for facemask sustainability issues, to study the decontamination of facemasks, and propose solutions, such as biodegradable feedstock, for facemask production and facemasks as a source of microplastics; how disposal procedures can potentially lead to the contamination of water resources has been reported too. The potential of developing nanomaterial-based antiviral and self-cleaning facemasks for multifunctional facemasks, including the use of metal-based coatings, are proposed too. Finally, it is concluded that the use of sustainable and alternative facemask materials is a promising and viable solution in this regard.

\section{Filtration Mechanism in Facemasks}

Masks are intended to provide protection against expelled droplets or aerosol particles in the environment or protect healthy individuals from infected mask wearers, as shown in Figure 3 [8,9]. In this context, masks are generally divided into four different categories based on their filtering capacity:

(i) Tailor-made fabric masks.

(ii) Surgical masks developed from nonwoven materials used for normal medical application.

(iii) Respiratory masks such as FFP1 (80\%), to FFP2 (94\%), and FFP3 (99\%) from the European Union (EU) and N95 (95\%), to N99 (99\%), and N100 (100\%) from the United States [10,11].

(iv) Occupational protective masks used against the particulate and gas respirators [12].

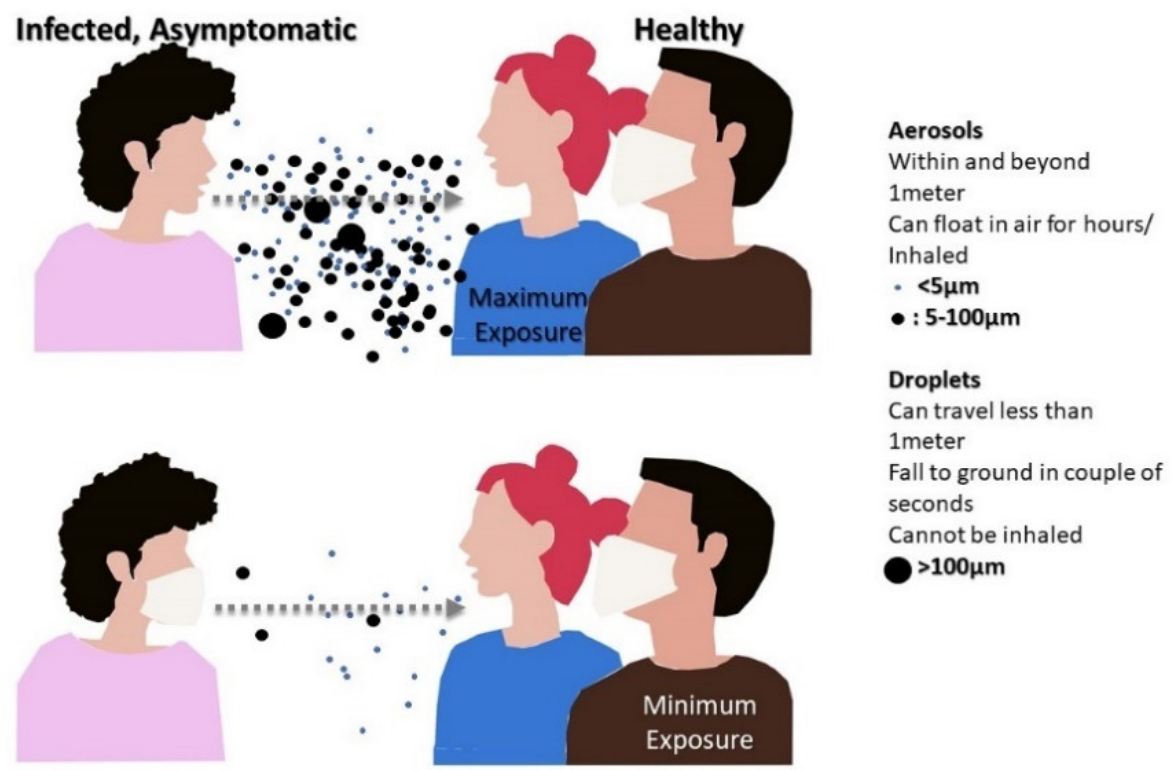

Figure 3. Infectious aerosol particles can be released during breathing and speaking by asymptomatic, infected individuals. 
As per the Committee on the Development of Reusable Facemasks for Use During an Influenza Pandemic, masks are classified as respirators and medical masks or facemasks [13]. Chan and Yuen have stated that respirators are designed to reduce the exposure of airborne particles and are also known as "disposable filtering half-facepiece respirators" [14], while medical masks are designed to prevent the transmission of droplets from health care workers to patients and vice versa [14]. Generally, a specific type of facemask is intended to filter particulates, categorized in different sizes (ultrafine particles $<0.1 \mu$ (PM0.1); fine particles <0.1-2.5 $\mu$ (PM2.5); coarser particles <2.5-10 $\mu$ (PM10)) [7,15].

There have been several mechanisms proposed to explain the air filtration phenomenon of face coverings. These mechanisms can be predominantly divided into steady state and non-steady state. Classically, a steady-state mechanism can be categorized as impaction, interception, and diffusion that mainly depend on the particles' size, as illustrated in Figure 4a. In addition, it has reported that electrostatic and the gravity effect are other trapping mechanisms, as shown in Figure 4b [16,17].

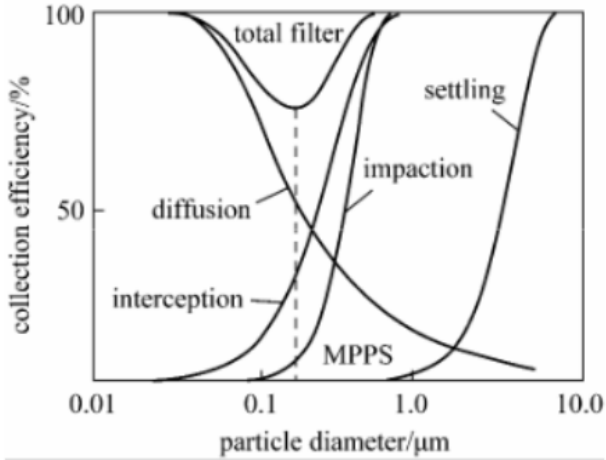

(a)

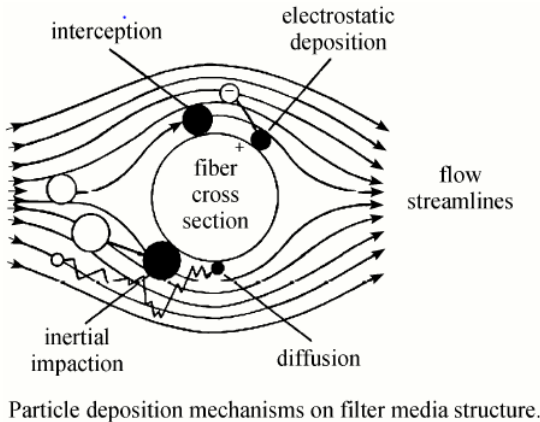

(b)

Figure 4. (a) Air filtration mechanisms and efficiency. (b) Aerosol filtration mechanism illustration $[16,17]$.

In order to understand the effectiveness of facemasks against the transmission of respiratory diseases, it is important to consider the particles involved in virus spread and their related characteristics. Respiratory pathogens such as coronavirus may transmit to humans through airborne routes, such as droplets and aerosols, apart from contact transmission through fomites $[18,19]$. Since facemasks are utilized primarily to prevent airborne transmission, few details have been provided on contact-based transmission.

The modes of droplet and aerosol transmission have been found to be characteristically different. If the size of a particle generated through coughing, sneezing, or voicing of a person is bigger than $5 \mu$, then spread is said to be transmitted through a droplet route $[20,21]$. The droplets are expected to disperse over shorter distances $(<1 \mathrm{~m})$ and remain in the air for less than $17 \mathrm{~min}[18,22]$. Thus, these particles may constitute a lower risk if proper social distancing norms are maintained. However, such droplets may travel more extensively due to environmental conditions such as temperature, humidity, or the presence of wind [23]. In contrast to the droplets, aerosols involve particle with a size $<5 \mu$, which are reported to stay in the air for infinite time with the ability to disperse over longer distances $(>1 \mathrm{~m})$ [18]. It is also important to note that droplets are not only generated through sneezing or coughing, as speaking can produce droplets of varying size and number. For instance, Anfinrud et al. have reported the generation of droplets ranging from 20 to $500 \mu$ when a person says "stay healthy" [24]. In such conditions, facemasks may serve as physical barriers to these respiratory droplets. Kähler and Hain have further extended the importance of creating physical barriers in the form of facemasks against the spread of respiratory droplets [25]. The authors have experimentally demonstrated that a single, strong cough was not able to disperse longer than $1.5 \mathrm{~m}$ due to the reduced flow velocity in the stream-wise direction. However, a longer cough was able to be projected over longer distances, as shown in Figure 5 top and middle. The authors have further 
demonstrated the role of a surgical mask in effectively inhibiting the airflow generated during coughing. In the presence of a surgical mask, the high velocity air movement was converted into a unidirectional, low velocity air jet flow, as shown in Figure 5 lower left. The presence of face coverings was primarily observed to create a pressure difference that dispersed the direction of flow in all directions and subsequently reduced the ability of the flow to transmit longer in the air. The effectiveness of masks can be clearly gleaned from Figure 5 lower right, where a person is exhaling more droplets when talking without a mask than coughing with a mask (Figure 5 lower left). Based on the results obtained in this study, the authors advocated that even the use of simple mouth-nose coverings are efficient in preventing the spread of respiratory diseases to some extent.

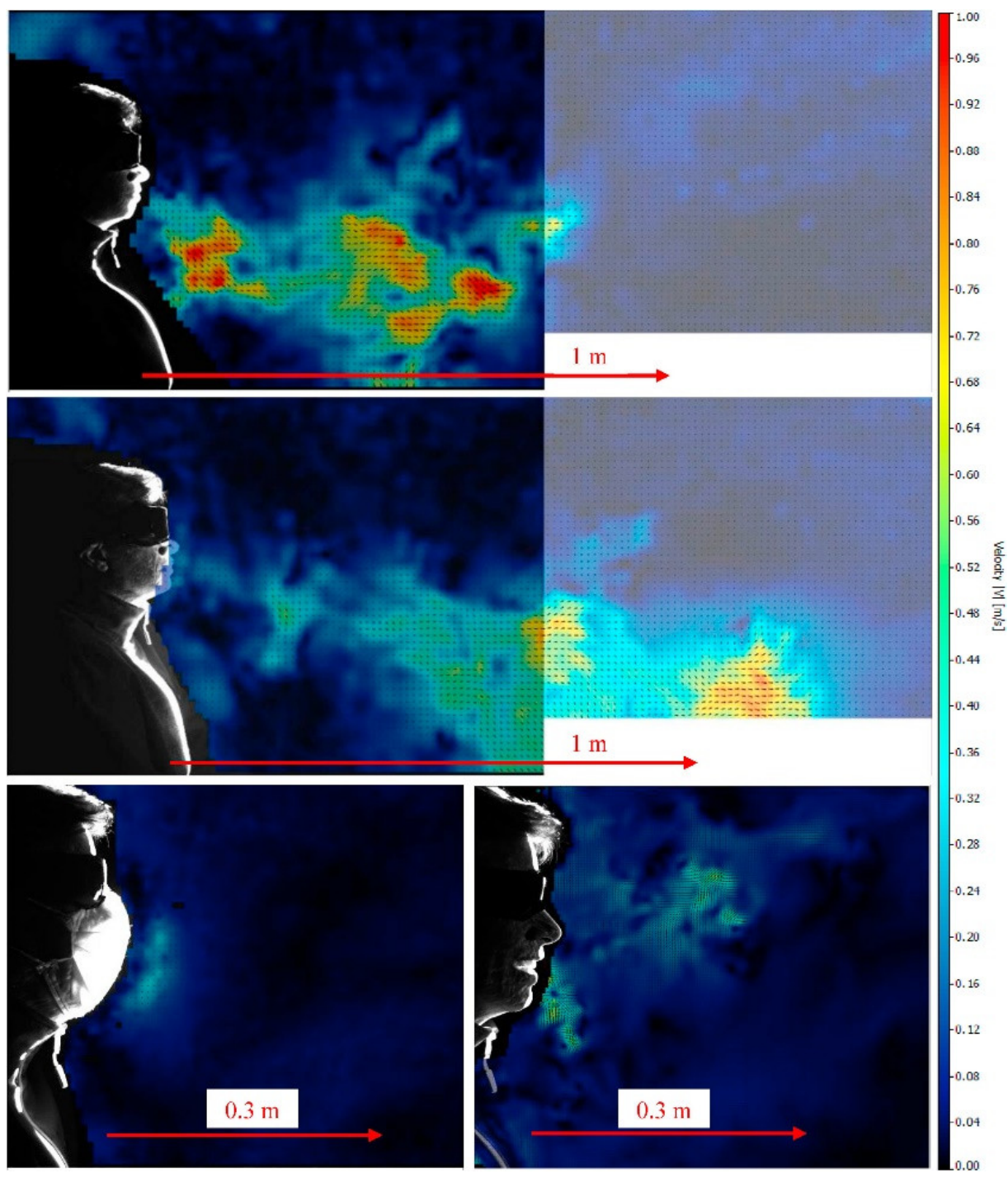

Figure 5. Instantaneous flow field when coughing over one breath without a mask (top). Flow field when coughing over a longer period of time without a mask (middle). Flow field when coughing over one breath with a mask (lower left), and instantaneous flow field when talking without a mask (lower right) [25].

The effectiveness of any mask is not only dependent on its type; it also depends on the mask's fit and how it is worn. Authors have strongly recommended that the efficiency of masks is not consistent and is largely affected by the cough cycle, face fitting, time of exposure, and environmental conditions. Some if these variables are largely subjective to the facemask users, which has been difficult to replicate in a lab setting. It is believed that the use of facemasks helps to reduce the transmission and spread of airborne particles, but 
they still do not provide full protection, as droplets may spread around the facial covering during the cough cycle [23]. Figure 6a exhibits the visualization of flow escaping from a mask wearer during a coughing incident (at $t=3.06 \mathrm{~s})$. The droplet leakage from a mask is believed to be facilitated by the pressure differential between the environment and the volume behind the mask. Figure $6 \mathrm{~b}$ shows the effectiveness of using a facemask, which indicates that wearing a facemask not only inhibits the transmission of droplets but may also reduce droplet exposure if the recipient is also using a facemask.

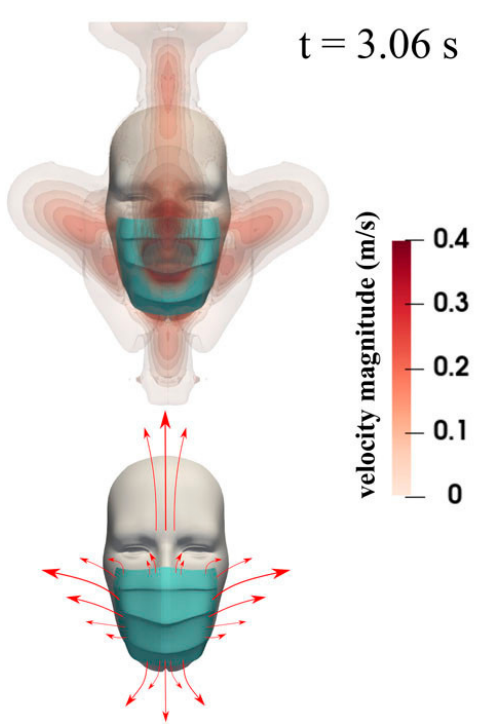

(a)
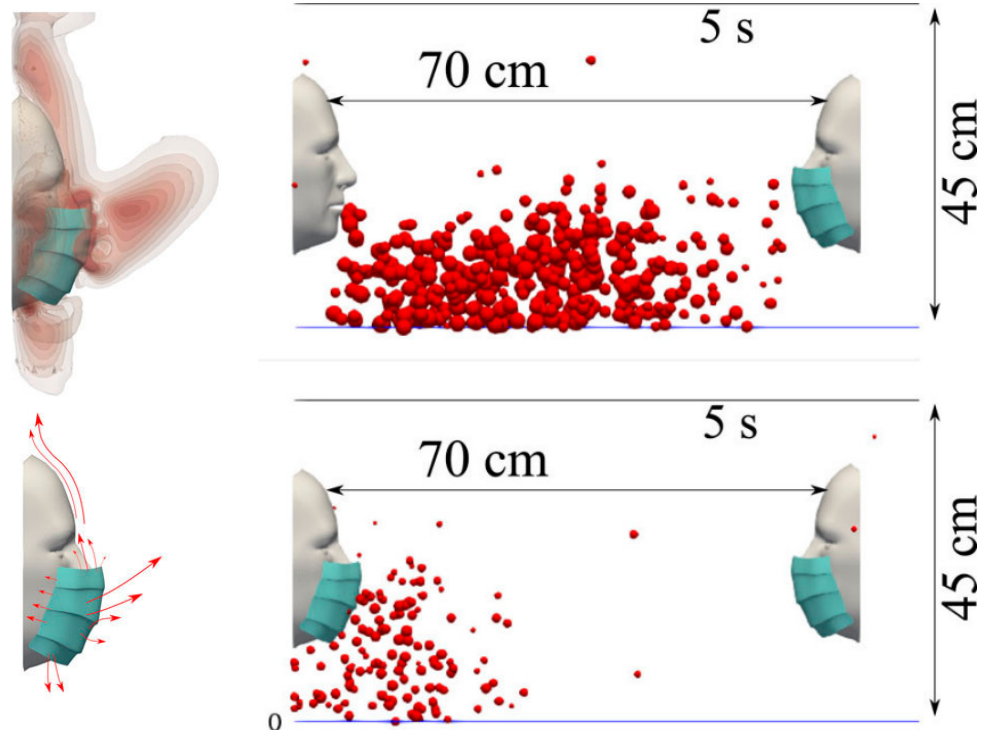

(b)

Figure 6. (a) A subject coughing while wearing a surgical mask. The top figures show the velocity magnitude contours at $t=3.06 \mathrm{~s}$. The bottom figures show a schematic of the flow dynamics. (b) Mask wearer: subjects wearing a mask will reduce their respiratory droplet transmission while (partially) shielding themselves from other subjects experiencing a coughing incident. The results shown are at a $5 \mathrm{~s}$ simulation time for a surgical mask exhibiting an initial efficiency of $\sim 91 \%$. The environmental conditions are zero wind speed, ambient temperature $20^{\circ} \mathrm{C}$, pressure $1 \mathrm{~atm}$, and relative humidity $50 \%$. The mouth temperature is $34{ }^{\circ} \mathrm{C}$ and the face skin temperature is $32{ }^{\circ} \mathrm{C}$ [23].

Following government advisories to use facemasks, cloth-based facemasks or facecovering have become the new normal worldwide. However, conclusive scientific evidence remains outstanding to support of the effectiveness and efficacy of DIY facemasks for reducing the spread of respiratory viruses, such as COVID-19. Some previous studies on cloth-based facemasks have demonstrated that cloth masks are marginally effective against the particle size $<2.5 \mu$. For instance, Shakya et al. studied the effectiveness of four different types of masks against five different types of monodispersed aerosols (particle sizes of $30 \mathrm{~nm}, 100 \mathrm{~nm}, 500 \mathrm{~nm}, 1 \mu \mathrm{m}$, and $2.5 \mu \mathrm{m}$ ) and diluted whole diesel exhaust. The authors concluded that the efficiency of cloth masks against the standard studied particle sizes was in the range of $39 \%$ to $65 \%$, and their efficiency and repeatability was largely dependent on particle flow rate. Similarly, Davies et al. stated that DIY masks should be considered as a last resort to prevent droplet transmission [26]. In the same study, a surgical mask was found to be three times more effective than a DIY facemask at stopping droplet transmission. It is important to note here that most of the previous studies did not consider the efficiency of the facemask with respect to their weave density, weave structure, hybridization with other cloth type (natural, synthetic, or blend), number of layers, flow rates, or rate of impingement of aerosol particles in addition to environmental conditions $[8,27,28]$. For instance, Konda et al. have reported that the filtration efficiency of single-layer fibers of cotton, silk, chiffon, and flannel was found to be in the range of 5 to $80 \%$ and 5 to $95 \%$ for particle sizes of $<300 \mathrm{~nm}$ and $>300 \mathrm{~nm}$, respectively [27]. 
The authors have reported that the filtration efficiency was dramatically enhanced when fabrics were hybridized with each other. The obtained efficiency was observed to be $>80 \%$ (for particles $<300 \mathrm{~nm}$ ) and $>90 \%$ (for particles $>300 \mathrm{~nm}$ ). The study demonstrated that if facemask fabrics contain higher thread counts with tighter weaves, they can exhibit substantial filtering efficiencies. However, the proper fitting of the mask to the wearer's face without any gap or opening is still the most essential parameter in achieving the full potential of any mask. Hancock et al. have pointed out that the face velocity, or the average rate of impingement of aerosols on filtration media, is a vital parameter when studying the filtration efficiency of a facemask [28]. Konda et al. did not specifically focus on the face velocity or the rate of impingement for their determination of filtration efficiency for the masks used in their study [27]. Hancock et al. have demonstrated the linear dependency of a pressure drop on face velocity and pointed out that low velocity impingement, or low face velocity, is susceptible to error and may result in the high filtration efficiency observation in the study by Konda et al. [27,28]. It is also essential to understand that facemasks cannot be designed only for filtration or inhibition of viruses but must include comfort and breathability. Hancock et al. have illustrated that the comfort and breathability of a fabric can be associated to the material impedance, which is significantly influenced by the number of layers, weave type, threat count, and type of textile. Apparently, it is observed that increasing the thread count and number of layers in a mask increases the material impedance and simultaneously reduces the comfort and breathability. Additionally, higher material impedances indicated a compromised degree of protection due the leakage of unfiltered air flow tributaries. In another study conducted by Zangmeister et al., it was shown that the fabric parameters (yarn counts, fabric type, and weave) hold complex relationships with the filtration efficiency of nanosized aerosol droplets [8]. They studied the filtration efficiency, differential pressure, quality factors, and construction parameters of 32 cloth materials. The authors concluded that $100 \%$ cotton cloth with a high to moderate yarn count and two woven, synthetic cloths with moderate yarn counts demonstrated the best performance against aerosol droplets in the size range of 50 to $825 \mathrm{~nm}$. It is evident from the various studies that cloth-based masks can be recommended for use by the general public, but their efficiency and performance and their related variables are yet to be established. Therefore, WHO guidelines which state "The use of masks is part of a comprehensive package of the prevention and control measures that can limit the spread of certain respiratory viral diseases, including COVID-19" must be adopted to the prior variables. However, the use of a mask alone is insufficient in providing an adequate level of protection or source control. Additionally, personal and community level measures should also be adopted to suppress transmission of respiratory viruses [29].

\section{Facemasks as a Source of Microplastics and Nanoplastics}

There is an increasing concern over the management of new emerging wastes, socalled "COVID wastes" - gloves, masks, and bottles of hand sanitizers (see Figure 7). The challenge of microplastics (MP) emission from facemasks is a relatively new issue due to the use of measures to suppress the spread of COVID-19 [30-32].
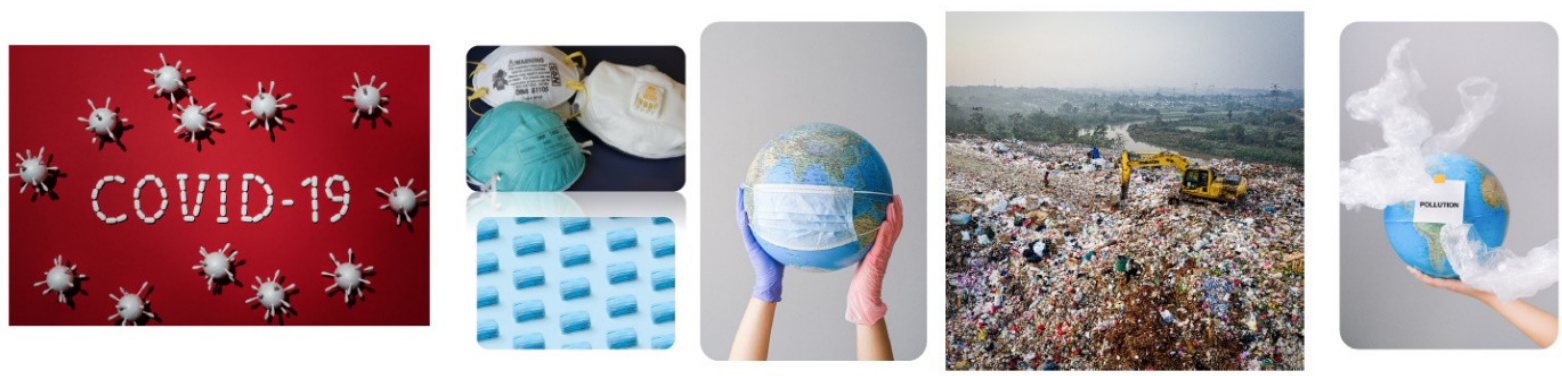

Figure 7. Facemask environmental challenge. 
Respiratory route transmission of the novel virus (vide infra) [31] was the reason for many governmental policies encouraging, or requiring, the use of facemasks [10,33-35]. The increased usage of facemasks resulted in a dramatic increase in their production [35], and shortages in masks drove people to self-produce masks from household items [31,36]. Generally, all masks and respirators may be reusable (including industrial-use half or full facepiece respirators with cartridge filters attached and homemade or commercial cloth masks) or disposable (such as surgical masks, N95 respirators, and KN95 respirators) [2]. Due to the SARS-CoV-2 size ranging from 60 to $140 \mathrm{~nm}$, masks and respirators made of materials with larger pore sizes, such as cotton and synthetic fabric, are inefficient at filtering SARS-CoV-2 [31].

The increased feedstock demand for facemask production led to the generation of huge amounts of wastes worldwide. The calculations considering UK inhabitants [20] indicate that if every person in the UK uses one single-use mask each day for a year, 66,000 tons of contaminated plastic waste will be generated, without counting the waste from packaging. It was estimated that, as the consequence of the COVID-19 pandemic, the demand on plastics will increase by $40 \%$ in packaging and $17 \%$ in other applications, including medical uses [10]. It is reported that the amount of medical waste significantly increased recently, up to $350-370 \%$, in countries such as Spain and China [10].

Among the various types of facemasks, the most commonly used are surgical facemasks and N95 respirators [20]. Three-ply surgical masks are composed of three different layers, each made of a nonwoven fabric and having a specific function. The typically blue outermost layer is made of a waterproof nonwoven fabric (usually a polypropylene), and its role is repelling fluids such as mucosalivary droplets. In the middle of the mask there is a melt-blown filter layer preventing certain size particles, or pathogens, from penetrating in either direction. The layer closest to the face (inner layer, made of soft fibers such as high-density polyethylene) is designed to trap mucosalivary droplets (including moisture) from the user and is made of absorbent materials. The combination of these three layers is recognized as an effective barrier and a protecting agent not only for the user but also for the surrounding people due to the reduced penetration of particles and pathogens in both directions $[20,33,37,38]$.

Nonwoven fabrics not containing intertwining strands (bonded by thermal, chemical, or mechanical techniques) are often used in surgical masks due to their low price and easy maintenance, despite their poor mechanical performance [20]. Due to its relatively low price, low melt viscosity, and facile processing, polypropylene is the most common feedstock for facemask production; however, other materials such as polystyrene, polycarbonate, polyethylene, and polyester are also used $[10,20,39]$. The increased demand for protective agents has resulted in establishing materials for mask production with enhanced properties; for example, self-disinfecting, antimicrobial activity, and superhydrophobicity [20,31].

WHO estimations indicate that approximately 89 million medical masks are needed monthly worldwide [31]. It is recommended to discard surgical masks and gloves after a few hours to avoid cross-contamination [10]. Considering that a single N95 mask uses around $9-11 \mathrm{~g}$ of polypropylene, and a single disposable surgical mask uses $4.5 \mathrm{~g}$ of polypropylene and other derivatives of plastics (e.g., polyethylene PE, polyurethane PU, polystyrene PS, polycarbonate PC, polyacrylonitrile PA) [35], the amount of generated plastic wastes from used facemasks is not inconsiderable. Additionally, most plastics are non-biodegradable (due to their molecular stability, hydrophobic properties, high molecular weight, and high surface roughness), and their complete degradation/mineralization is not witnessed in reasonable timelines [35,40]. Significant increases in the usage of facemasks, and therefore their production, are expected, which will potentially lead to a severe problem in the environment due to the increase of solid wastes [33,41]. Therefore, the problem of environmental pollution by facemasks is not only global-atmospheric, but also extends to affecting the aquatic environment. Plastics and microplastics are able to invade almost every ecosystem [35]; microplastics were noted even in the packed ice of the Arctic ocean (up to $2 \times 10^{6}$ particles $/ \mathrm{m}^{3}$ ) [42]. 
Facemasks can be mistakenly recognized by animals (fishes, etc.) as substances, affecting the food chain and consequently causing health problems to humans $[33,35]$. Facemasks are dangerous for water organisms due to the presence of straps that can trap the animals [34]. Facemasks prepared using plastics are a potential source of pollution of the environment by microplastics. That makes the problem of facemask management nowadays an issue of key importance [43].

There have been several reports on the microplastic pollution of different plastic products, impacts, and controlling mechanisms. In recent years, medical facemasks, manufactured from plastic polymers, have become a significant source of microplastics pollution. While their lifecycles in the ecosystem are not fully understood, neither are their effects fully considered [33]. COVID-19 is playing a key role in microplastics pollution [31], and surgical facemasks and gloves should be investigated as a significant source of microplastics, such as polypropylene (PP), polyethylene terephthalate (PET), and polyethylene $[10,33]$ as a result of their disposal in landfills, dumpsites, freshwater and marine environments, or littering in public spaces. Under environmental conditions, facemasks can be altered or broken down as a result of high temperatures, UV exposure, or simply a change in $\mathrm{pH}$ (chemical attack) [35].

The route of microplastic-to-human interaction involves the respiratory system or the gastrointestinal tract (by means of $\mathrm{M}$ cell-mediated endocytosis mechanisms or paracellular transport) [44]. The studies on the microplastic inhalation hazards of facemasks have not been extensively understood nor reported yet. However, it was shown that masks (surgical, cotton, fashion, and activated carbon masks) pose high fiber-like microplastic inhalation risks, while reusing masks increases these risks [30]. The results were strictly connected with the time of the usage, and N95 masks possessed the lowest microplastic inhalation risks in the long term when compared to surgical masks. The other key parameter in the potential microplastics inhalation risk was the shape of the microplastics. The masks, except N95, possessed higher stripe-type microplastic inhalation risks, whereas wearing N95 masks posed considerably lower spherical-type microplastic inhalation risks [30]. Interestingly, an increased risk of particulates (e.g., granular microplastics) and fiber-like microplastic inhalation was noted for disinfected, reused masks, whereas the disinfection mode affected the results. Ultraviolet disinfection is recommended as a treatment process for reusing masks as a means for reducing the amount of used masks [45]. It exerts a relatively weak effect on fiber-like microplastic inhalation. It is worth mentioning that N95 masks reduced the inhalation risk of spherical-type microplastics by 25.5 times compared with not wearing a mask [30].

Microplastics can easily enter the human body and accumulate [44]. Studies in literature have revealed the presence of pigmented spherical microplastics, as well as irregular shaped microplastics, made from polypropylene. They were small enough (5 to $10 \mu \mathrm{m}$ ) to be transported by the bloodstream and were coming from cosmetics, textile (cotton/polyester) dyeing, coating products, adhesives, fragrances, and air fresheners. Additionally, adsorbed microplastic pollutants can cause long-term effects on human health [44]. The presence of microplastics induces and/or enhances immune responses that can potentially reduce the defense mechanisms against pathogens and alter the utilization of energy stores. Microplastics were detected in human placentas, indicating the great risk of transportation of these pollutants throughout maternal, fetal, and amniochorial membranes [44].

\subsection{The Challenges with Landfilled Facemasks Waste}

The annual production of plastics was estimated at above $3 \times 10^{8}$ tons [46,47]. It was estimated that the usual medical waste generation of 275 tons/month during normal periods was multiplied by a factor of four (up to 1200 tons) during the COVID-19 pandemic [46]. Considering the potentially infectious nature of used facemasks, some countries recommended treating them as infectious or mixed wastes (not recyclables) that need to be incinerated or carefully landfilled (and/or sterilized before landfill) [6,10]. In other 
countries, the COVID-19 pandemic has resulted in the reduction or even discontinuation of recycling programs, which may negatively affect the environment [10].

Strategies to better manage medical and plastic waste should include the improvement of municipal waste-management programs [48]. The infected plastic waste should not be a part of the municipal solid waste recycling stream due to the high risk of viral transmission to the people involved in collecting, transporting, and management of the wastes [49] It is estimated that nearly $90 \%$ of wastes are discharged directly or indirectly into the soil [47]. The most important environmental parameter connected with facemasks is not only their gross tonnage, but also their general impact on the environment once there. Performed sparse life cycle assessments (a method of determining an environmental footprint considering the whole lifecycle, i.e., a cradle-to-grave paradigm) of facemasks and COVID-19 wastes have indicated that reusable masks without filters treated simply (e.g., washing in a washing machine) had the lowest contribution to climate change $\left(<2.00 \times 10^{8} \mathrm{Kg} \mathrm{CO}_{2}\right.$ eq), whereas the effect of single-use masks and reusable masks with disposable filters had the highest contribution to climate change $\left(\sim 1.47 \times 10^{9}\right.$ and $1.50 \times 10^{9} \mathrm{Kg} \mathrm{CO}_{2}$ eq, respectively) [10]. The data clearly support the assessments that the effect of single-use facemasks is up to 10 times higher on the environment that reusable ones. Considering the predicted amount of facemasks, the emissions of greenhouse gases (GHG, such as $\mathrm{CO}_{2}$ and $\mathrm{CH}_{4}$ ) may reach, for example in the UK, 178,200 tons each year [20].

The emissions of GHG are observed not only during plastic and facemask production but also during their most popular management methods, which are incineration and decomposition in landfills [49]. Incineration, although recommended as an efficient method of decontamination, may be connected with the release of hazardous chemicals (heavy metals, dioxins, PCBs, dioxins and furans). Some studies indicate that the phasing out of single-use plastics in Europe prevented the emission of 3.4 million tons of $\mathrm{CO}_{2}$, environmental damages with a predicted cost of EUR 22 billion by 2030, and consumer costs of EUR 6.5 billion [10].

The storage of wastes in a landfill is the most widely used way of plastics disposal; however, there are several issues connected with it. Microplastics were noted not only in the marine environment, which is the most presented in literature [50,51], but also in soil, although the data on soil microplastics pollution are scarce. Microplastics in soil are introduced via primary sources (e.g., industrial or domestic) and secondary sources (e.g., plastic mulch, household waste) [47]. Soil amendments, irrigation, flooding, atmospheric input, and mode of incorporation also affect the amount and fate of microplastics in soil [35]. Any technique of wastes management, with the exception of incineration, is connected with microplastics emission. It was evidenced that composting plastic wastes introduced up to $2.38-1200 \mathrm{mg}$ plastic/ $\mathrm{kg}$ of microplastics into the soil. Higher amounts of microplastics were noted in wastewater and sewage sludge (24,000 plastic items $/ \mathrm{kg}$ and 125,000 plastic items $/ \mathrm{m}^{3}$, respectively). Flooding has a significant impact on microplastics input into soils (lake water up to 4.42 plastic items $/ \mathrm{m}^{3}$ and river water up to 13,751 items $/ \mathrm{km}^{2}$ ) [46]. Soil is a great reservoir of microplastics, as most plastics (especially $>1 \mu \mathrm{m}$ ) are retained in the soil. Here, plastics are subjected to several environmental processes and microbial-plant-animal interactions, including weathering, hydrolysis, erosion, animal feeding (e.g., earthworms), and microbial action $[46,47]$. Data from China indicated that $100 \%$ of measured agricultural soils (Shaanxi, northwestern China) contained microplastics with concentrations ranging from 1430 to 3410 items $/ \mathrm{kg}$, with concentrations in coastal areas significantly higher-up to $14,712.5$ items $/ \mathrm{kg}$ [47]. On sandy beaches and the sea surface, significant concentrations of PP (36 particles $\left./ \mathrm{m}^{2}\right)$ and PE (228 particles $\left./ \mathrm{m}^{2}\right)$ were noted [35]. Considering the predicted increased facemask usage, facemasks will likely contribute to this microplastic challenge.

The greatest problem with microplastics in soil is related to their unknown environmental influences. It was shown that microplastics can move downward in the soil profile through bioturbation [47]. Bioturbation describes the transfer and transport of microplastics by external attachment to animals or by ingestion and excretion by soil fauna (e.g., larvae, earthworms, vertebrates) and poultry [47]. Digging mammals (e.g., ground squirrels and 
moles) and soil organisms that scrape or chew, such as mites (i.e., Hypoaspis aculeifer) and collembola (i.e., Folsomia candida and Proisotoma minuta), are major microplastic transporters in soils. A predator-prey relationship amongst soil micro arthropods may also promote the migration of microplastics [47]. Plants, another part of soil ecosystem, also affect the fate of microplastics in soil due to root disturbances, such as root movement, expansion, absorption, and rhizosphere hyphae [47]. Although traditional farming practices affect only the topsoil, the harvesting of tubers (e.g., potatoes and yams) may facilitate the vertical migration of microplastics.

The effects of microplastics on soil and water envrionments are diverse [52]. Some literature data have indicated that microplastics have the potential to improve the soils' fertility as a source of carbon (increase in fulvic and humic acids) and increase the water holding capacity and nutrient availability related to the humus content due to increased soil enzyme activity (urease and diacetic acid luciferin hydrolase, for example, by PA, PE, and PET) and the accumulation of soluble nutrients [47]. On the other hand, plastic residues can reduce some soil properties, such as PS and PET, which lowered the metabolic activity of soil microorganisms. Similarly, microplastics affect the abundance of both oxybiotic and anerobic microbes or fungi, where microplastics are a habitat for microorganisms, thus fostering a new ecological niche [47].

The effects on plant and animal growth and function, considering the presence of MP in the environment, are to the contrary. The presence of microplastics in soil can affect the vegetative period [47]. Some microplastics may reduce biomass (e.g., PLA for maize, or PVC for cress), while others (such as PE for maize and both PP and PE for cress) revealed no toxicity [47]. Interestingly, biodegradable plastic film composed of starch-based microplastics was more toxic to cress than PE. The negative impact of microplastics on marine zooplanktons was noted $[53,54]$. These studies indicated that all of the measured living parameters (reproduction, lifespan, feeding behavior, and growth) were lowered, for example, in cases of PS for copepod Calanus helgolandicus and gastropod Crepidula onyx [51,55]. Microplastics tend to cumulate in living organisms. Microplastics represented half of the fish larvae density of estuarine and mangrove larvae (e.g., Anchovia clupeoides, Gobionellus oceanicus), and after ingestion, gut blockage and starvation were induced [53]. An additional problem with landfilling of plastic wastes is air contaminantion. Microplastics are generally found in the atmosphere, posing health risks due to their small size. Microplastics in the air are largely represented by microfibers (67\%), micro fragments (30\%), and granules (3\%) of PE, PET, PP, PVC, and PS [42].

\subsection{Releasing of Viruses and Bacteria from Facemask Waste}

The increasing amount of COVID-19 wastes is connected with problems regarding their proper disposal due to both environmental and health concerns [56,57]. It was reported that COVID-19 viral RNA could contaminate numerous surfaces for several days [58]. The coronavirus can survive on paper or cardboard for a short time, up to $3 \mathrm{~h}$ or 1 day, respectively, whereas the presence of infectious SARS-CoV-2 on plastic surfaces was noted up to three days [10] with confirmed 6 days on the outer layer of a surgical mask [49]. Improperly disposed facemasks in the environment are convenient media for disease outbreak. Plastics and microplastics are recognized as media for propagating the growth of microbes (biofilm), including pathogens [59], which are especially dangerous for workers managing wastes. Additionally, the presence of biofilms on microplastics affect their buoyancy both in the natural environment and in wastewater treatment plants [42]. It is recommended to incinerate (at high temperatures, ensuring sterilization) infectious medical waste and landfill the residual ash [48].

Although facemasks are designed to reduce the release of coronavirus and influenza from an infected person [20], they are potential media for transporting pathogens. Furthermore, when disposed of improperly, they are an additional source of microplastics. Microplastics attached to microorganisms constitute a microplastisphere. These are a habitat and reservoir for different microorganisms (algae, protists, viruses, fungi, 
bacteria), including pathogens (such as Pseudomonas, Escherichia), fish pathogens (Aeromonas salmonicida), and human pathogens (Bacillus cereus, Stenotrophomonas maltophilia, Vibrio parahaemolyticus) [42,47]. Microplastic biofilms may be considered as breeding grounds for vectors of zoonotic diseases, such as dengue and Zika (mosquito Aedes spp.) [10].

Generally, plastic particles create a niche for microbial and developing biofilms, as microbes tend to proliferate on them. What is the most dangerous is that the microbial constituents may significantly differ from naturally living microorganisms [33]. Interestingly, the total abundance of pathogenic microbes on microplastics, as compared with other natural particles, may actually be similar [60]. Microplastics may also act as long-distance transport mechanism vectors for the spread of antimicrobial-resistant pathogens, as their concentrations were 100-5000 times higher on microplastics than in the surrounding seawater [61]. On the other hand, it was noted that microorganisms (or bioaerosols), such as bacteria, viruses, and fungi present in the air, can adhere to a filter surface, such as a facemask, and survive and reproduce within the filter media (which pose a risk of second airborne contamination). In an experiment, it was enough to touch an infected surface for $5 \mathrm{~s}$ to transfer $32 \%$ of influenza A viruses to hands [49]. Biofilms themselves are also responsible for altering the surface of microplastics, affecting their fragmentation or masking their surface properties, which affects their fate in the environment and makes their analysis difficult [42].

\subsection{Interaction of Microplastics with Other Materials including Hazardous Materials}

The presence of microplastics in the environment is connected with their influence on, and interaction with, other materials [62-64]. MP surfaces have large surface-area-tovolume ratios and chemical compositions that favor adsorption processes; hence, various organic and inorganic pollutants can be absorbed on their surface [64]. As such, MPs may transport other matter in the environment [65]. It was shown that on microplastics, metals and organics adsorbed and desorbed effectively [42] (i.e., a "Trojan horse" effect). Microplastics are excellent sinks for microorganism colonization and chemical adsorption [42], which makes them long-distance transportation systems, enhancing health risks for living organisms. Among the tested chemicals, the adsorption of metals ( $\mathrm{Ag}, \mathrm{Al}, \mathrm{As}$, $\mathrm{Ba}, \mathrm{Br}, \mathrm{Cd}, \mathrm{Cr}, \mathrm{Cu}, \mathrm{Fe}, \mathrm{Pb}$, and $\mathrm{Zn}$ ) and organics (polyaromatic hydrocarbons (PAHs), polychlorinated biphenyls (PCBs), the insecticide dichlorodiphenyltrichloroethane (DDT), and hexachlorocyclohexane isomers (HCHs)) were confirmed [66-68]. The concentrations of adsorbed organics reached levels up to several $\mu \mathrm{g} / \mathrm{g}$ of microplastics depending on both the microplastic and pollutant characteristics. Generally, chemicals were adsorbed preferentially onto PE followed by PVC, PP, or PS [42]. In the case of PS and ZnO nanoparticles, no antagonistic, synergistic, or additive effect was observed [69].

Research has shown that many impurities, i.e., phenanthrene, tend to accumulate on the surface of microplastics (especially PE) [54]. Additionally, leaching of various additives, plasticizers, and monomers (e.g., phthalates, bisphenol A, included in EDCs) have been noted. Plastic additives are designed to, for example, increase heat resistance (e.g., polybrominated diphenyl ethers), reduce susceptibility to oxidation (e.g., nonylphenol), or microbial degradation (e.g., triclosan) and are themselves toxic after release [54].

An additional threat resulting from the presence of nano and microplastics in the environment is their ability to adsorb various compounds. Although plastics are not characterized by a well-developed specific surface, they can, however, adsorb various types of pollutants (organic and inorganic), although in small amounts, but at a level that is toxic to living organisms. They may be specific sorbents or other pollutants present in water, such as heavy metals or organic compounds (i.e., PAHs, PCBs, EDCs). The adsorbed pollutants can then move or accumulate in aquatic organisms [50]. The desorption rate of adsorbed pollutants from microplastics in organisms was measured to be considerably faster than in water due to the presence of organic matter and surfactants [70]. Microplastics are subjected to the action of sun, water, wind, and living organisms; however, the response 
of microplastics to environmental parameters is diverse. For example, PE is relatively resistant to UV-C, but a UV induced treatment (depending on the dose) can reduce the surface hydrophobicity, thus affecting the affinity of UV-treated microplastics for organic contaminants (benzene and ciprofloxacin) [71]. Generally, larger and highly weathered microplastics, or microplastics in soil after long-term vegetable cultivation, absorb more hydrophobic substances (including antibiotics). Microplastics with adsorbed contaminants combined with leachable plasticizers or additives may form a mixture of hazardous contaminants, which can be toxic (for example, PE + Cd for root biomass), and also affect microbes that adhere to the microplastics [47]. However, the presence of biofilms on microplastics may enhance the removal of certain microplastics by sedimentation [72], thus removing them from their water matrix.

Microplastics themselves can cause several changes in organisms, including reduced photosynthetic efficiency, increased oxidative stress, endocrine disrupting action, DNA damage, and mutagenesis. Simply increased expression of stress defense enzymes, such as catalase, superoxide dismutase, glutathione S-transferase and glutathione peroxidase, and heat shock proteins (HSP70 and HSP90) may affect the toxicity of other contaminants [42]. Microplastics often induce cytotoxicity, translocation to other tissues [73], disruption of planned cell death (apoptosis), and development of necrosis [74]. In summary, the greatest threat connected with microplastics presence is their bioaccumulation in living organisms and their transfer to higher trophic levels. Potential metabolic disturbances, neurotoxicity, and an increased cancer risk are the main health hazards of microplastics for humans [73].

\subsection{Challenges for Wastewater Treatment}

The problem of pollution of the seas and oceans by macro and microplastics has been described and studied very extensively in literature [72]. It is estimated that up to $10 \%$ of produced plastics end up in the sea and oceans [54]. Plastics with a larger diameter (macroplastics) form the so-called islands of trash, where they disturb the aesthetics (which may affect tourism), pose a threat to the maritime industry (i.e., shipping, fishing, aquaculture), and have an impact on the health and condition of marine animals. The presence of garbage islands is disturbing the functioning of marine ecosystems: new habitats on macroplastics, seabed suffocation, etc. [75]. However, there are studies indicating that macroplastics would not serve as surrogates for microplastic items [76]. Wastewater treatment plants (WWTP) are considered as important point sources of microplastics that can be used for collecting and removing microplastics from wastewater [77,78]. Microplastics accumulate in wastewater treatment plants, where part of the microplastics are retained in the sediment [79]. On the other hand, the presence of nanoplastics can contribute to the inhibition of treatment processes in treatment plants [80]. Raw sewage influents have been measured, consisting of microplastic fibers $(60 \%$ and $90 \%$ of the total microplastics) $[81,82]$. The concentrations of notable microplastic were PP $(\approx 50 \%)$, followed by PE $(\approx 33 \%)$, nylon $(\approx 10 \%)$, and PS $(\approx 5 \%)$. In river water, this concentration was measured at 0.097 to 0.135 fibers $/ \mathrm{L}$, and 25.5 to 102.4 fibers $/ \mathrm{kg}$ were measured in shoreline sediment, which indicated that the microplastics originated from washing clothing [81-83]. A single washing cycle has been measured to be responsible for the release of around $1.9 \times 10^{3}$ plastic fibers. Considering the global annual production of synthetic fibers used for clothing stands at around $7 \times 10^{7}$ tons (11 kg per person [70]), the amount of MP in wastewater is enormous. The products of wastewater treatment (e.g., sewage sludge applied in agriculture in Europe) introduces 125 to 850 tons of microplastics per million inhabitants to soil annually [42], where the microplastic concentration in sewage sludge may reach $2.4 \times 10^{4}$ microplastics $/ \mathrm{kg}$ [46].

Except for wastewater treatment, sewage sludge processing includes anaerobic digestion systems, which may be hindered due to the presence of microplastics, and lower levels of methane have been noted. The presence of microplastics extended the start-up of mixed anaerobic digestion systems and affected the presence of microorganisms. Some of the microorganisms were hindered (family Cloacamonaceae, Porphyromonadaceae, Anaerolinaceae, 
and Gracilibacteraceae) whereas others (family Anaerolinaceae, Clostridiaceae, Geobacteraceae, Dethiosulfovibrionaceae, and Desulfobulbaceae) were enhanced [80].

Treated wastewater may be introduced into rivers and lakes. However, the amount of microplastics in freshwater environments is equivalent to that of marine ecosystems, though the type of microplastics may differ (for example, PET is noted primarily in freshwater) [42]. Generally, the amount of microplastics in wastewater differs depending on the location, but microplastics may be released into an aquatic environment from a secondary WWTP at a rate of, for example, $6.5 \times 10^{7} \mathrm{MPs} /$ day (Scotland) or $1.8 \times 10^{8} \mathrm{MPs} /$ day (Turkey) [42]. Although the removal efficiency of MPs in WWTP is described as high (90.3\% [42]), when the concentrations of predominately PA (polyamide), PP, PE, PET, PES (polyester), and HDPE (high-density polyethylene) in effluent (up to $9 \times 10^{3} / \mathrm{L}$ of WWTP in Germany) [42] are considered, the problem of microplastics in WWTP needs substantial attention. Data presented by Bläsing [46] on microplastic concentrations in untreated and treated wastewater $\left(1 \times 10^{3}-6.27 \times 10^{5}\right.$ and $0-1.25 \times 10^{5} \mathrm{MPs} / \mathrm{m}^{3}$, respectively) clearly imply that microplastics in WWTP are largely not being completely removed [77].

The differences in removal rates resulted from the different sizes of the tested microplastics. The application of aerated grit chambers enabled the removal up to $59 \%$ of large size films of microplastics $(1-5 \mathrm{~mm})$ from influent, and $90 \%$ of MP fragments were removed in settling tanks, with the removal rates of fragments > films > fibers being $90 \%>85 \%>70 \%$, respectively [72]. Furthermore, in addition to microplastics, their additives such as plasticizers (e.g., di 2-ethyl hexyl phthalate) can be introduced with treated wastewater into the environment [84].

\section{Decontaminating Facemasks}

The continuing global pandemic has caused a surge in facemask demand around the world, simultaneously increasing their use and indiscriminate disposal. To circumvent the challenges of facemask shortages and enhance their reusability, an alternative method for reusing facemasks has been contemplated, which has been coined as "decontamination or sterilization of facemasks". The decontamination process of facemasks should kill or inactivate pathogens on contaminated surfaces while maintaining the filtering performance and structural integrity of the mask [85]. It is very important to consider that decontamination, and the subsequent reuse of a facepiece respirator (FFR), should only be practiced where FFR shortages exist [86]. The process of decontamination should not leave any chemical or by-product on a facemask that may affect the health of the wearer. In general, any method of decontamination is intended to achieve the following objectives [87]:

(i) Facilitate the elimination of all pathogens.

(ii) Preserve the facemask structure after decontamination.

(iii) Maintain the filtration efficiency.

(iv) Eliminate all residues of the disinfectant.

In the view of the COVID-19 pandemic, there are several research studies that have dealt with the decontamination process and its effectiveness. For example, a prolonged storage strategy in conjunction with disinfection methods can be performed when sustaining for a couple of days is practical $[88,89]$. As viruses can survive for a couple of days, depending on certain factors such as surface, temperature, and humidity, the proper damping of discarded facemasks can kill the viruses after 10 days [89,90], which is practical for low-income countries. However, as the use/discarding of the facemask is a continuous process, there is a need to think about an alternative approach to be practical for various conditions.

The National Personal Protective Technology Laboratory (NPPTL) has conducted decontamination assessments of several respirator products. The assessments have been primarily focused on various commercially available N95 facemasks to quantify their filtration efficiencies [86]. In order to achieve a decontaminated facemask, a number of methods have been proposed, such as ultraviolet germicidal irradiation, moist heat incubation (pasteurization), microwave-generated steam, hydrogen peroxide vapor, bleach, microwave 
steam bags, steam, dry heat, ethanol or isopropyl alcohol, ethylene oxide, hydrogen peroxide gas plasma, liquid hydrogen peroxide, and microwave irradiation techniques [91]. In the event of dramatic shortages of FFR supplies due to a health pandemic, such as modern COVID-19 circumstances, multiple decontamination processing techniques may become necessary [92]. Based on this, The National Institute for Occupational Safety and Health (NIOSH) found that, as of April 2020, ultraviolet germicidal irradiation, vaporous hydrogen peroxide, and moist heat have shown to be the most promising methods to decontaminate FFRs [86]. However, the stated methods are limited to filtering facepiece respirators (FFR) (e.g., N95 masks) in shortage conditions. Below, we provide an overview of some of the main decontamination techniques, with detailed discussions of others available in further literature [20,41,93-97].

\subsection{Ultraviolet Germicidal Irradiation (UVGI)}

The relationship between humans and ultraviolet light cannot be stated in terms of a specific time frame. Indeed, it started with experience and later transformed from experiment into well-established technology. Hockberger [98] and Reed [99] have reported the detailed history of the development of UVGI technology for the inactivation of microorganisms. It was Downes and Blunt who first demonstrated that exposing microorganisms to sunlight can inhibit their growth [100]. The extent of inhibition was found to be dependent on intensity, duration, and wavelength in addition to UV doses. The technology continued growing after the work of Downes and Blunt, and in recent years, it has been actively utilized for decontaminating water, air, and virucidal surfaces [101]. In general, UVGI uses low pressure mercury $(\mathrm{Hg})$ discharge to emit UV-C of a 100-280 nm wavelength light, which inhibits the growth of microorganisms by damaging their deoxyribonucleic acid (DNA) through the formation of intrastrand cyclobutyl-pyrimidine dimers [102]. Apart from the formation of dimers, photohydration can additionally contribute to cellular inactivation under UV irradiation. In general, single-stranded RNA or DNA are more prone to UV inactivation as compared to double-stranded viruses. Additionally, enveloped viruses are more susceptible to UV than non-enveloped viruses, likely due to the facilitated disruption of their proteins and lipids [103].

\subsection{Vapor Hydrogen Peroxide (VHP)}

The hydrogen peroxide method of sterilization is a class of gaseous sterilization processes and is primarily related to an oxidizing agent-based disinfection method [104,105]. In general, hydrogen peroxide decontamination methods are carried out in two ways, including vapor and aerosol [105]. It was observed that hydrogen peroxide in a gaseous form was more effective than a liquid form, but the effectiveness of the gaseous form was primarily hindered by the water condensation on the target surface [104]. Therefore, in order to overcome low efficiency, hydrogen peroxide was stabilized by adding metal ions (e.g., silver, iron, copper, etc.), in addition to recently developed advanced oxidation techniques, such as cold plasma [106]. Alternatively, ozone and hydrogen peroxide can be combined to disinfect tap water. The main mechanism of disinfection is primarily related to the formation of $\mathrm{OH}^{-}$radicals, which are considered very strong oxidants [104]. The formed hydroxyl radicals are hypothesized to react with lipids, DNA, and double bonds of essential components [104]. In response to shortages of PPE during the pandemic, a decontamination method based on VHP was studied using a range of hydrogen peroxide concentrations to disinfect PPE, including facemasks [106]. Based on these tests of three biological indicators, namely Escherichia coli, Mycobacterium smegmatis, and spores of Bacillus stearothermophilus, it was observed that the VHP disinfection had no observable damaging effects on the physical features, permeability, or fabric quality of the facemasks. Moreover, it is suggested that a single VHP cycle could disinfect PPE, as noted by a complete sterilization of B. stearothermophilus spores [106]. 


\subsection{Microwave Decontamination}

Conventional heating systems (convective ovens or steamers) could be employed to treat reusable facemasks; however, most reusable masks have elastic ear loops to hold them in place. These elastic components are susceptible to heat, leading to rapid degradation. Unlike conventional heating, electromagnetic heating is due to a volumetric absorption of electromagnetic energy by the heated material $[107,108]$. This naturally leads to faster and more efficient heating in materials with reasonably high dielectric properties [107,109-112]. The power dissipated per unit volume in nonmagnetic, uniform materials exposed to electromagnetic fields can be expressed as [37]:

$$
P(x)=55.63 \times 10^{-12} \times f \cdot\left(\tau \cdot E_{0}\right)^{2} \cdot \kappa^{\prime \prime} \cdot e^{-2 k_{o} \alpha x}
$$

where $f$ is the frequency $(\mathrm{Hz}), k_{o}$ is the wavenumber of free space $\left(k_{o}=\frac{2 \pi}{\lambda_{o}}\right), \lambda_{o}$ is the wavelength of the electromagnetic wave in free space $(\mathrm{m}), \alpha$ is the attenuation factor $\left(\mathrm{m}^{-1}\right)$, and $x$ is the distance below the surface of the material $(\mathrm{m})$. The attenuation factor in a material is determined by:

$$
\alpha=\frac{2 \pi f}{c} \sqrt{\kappa^{\prime} \frac{\sqrt{1+\left(\frac{\kappa^{\prime \prime}}{\kappa^{\prime}}\right)^{2}}-1}{2}}
$$

where $c$ is the speed of light in a vacuum $\left(\mathrm{m} \mathrm{s}^{-1}\right)$.

The electromagnetic heating rate depends on the specific heat capacity $(\mathrm{C})$ and density $(\rho)$ of the material $[113,114]$ :

$$
\frac{d T}{d t}=\frac{P}{C \rho}
$$

Examining Equations (1) and (3), it is apparent that the rate of electromagnetic heating is directly dependent on the operating frequency of the system and the dielectric loss factor of the heated material. The heating rate is also proportional to the square of the electromagnetic wave's electric field strength. The heating rate is inversely proportional to the specific heat capacity and density of the material. Clearly, the dielectric properties of the material strongly influence the heating rate. Dry textiles have naturally low dielectric properties, ranging between 1.1 and 2.0 for their real part $\left(\kappa^{\prime}\right)$ [115]. The loss factor $\left(\kappa^{\prime \prime}\right)$ for dry textiles is also very low. The dielectric properties of most fibrous materials, both natural and synthetic, increase significantly with moisture content $[116,117]$; therefore, a significant localized electromagnetic heating of fabrics can be achieved by wetting the parts of the fabric that need treatment. In this way, wetting of the mask area, without wetting of the elastic ear straps, would result in localized volumetric heating of the moist fabric with very little heating of the elastic components. The localized generation of steam in the moist fabric would act as a transport mechanism for the generated heat [118] and also assist in disinfection of the masks. In a work that was performed by Bergman et al. [92], different surgical N95 FFR models were decontaminated with ultraviolet germicidal irradiation (UVGI), moist heat incubation (MHI), or microwave-generated steam (MGS) methods. After decontamination cycles, MGS and MHI treatments caused one FFR model to experience a slight separation of the inner foam nose cushion, or a melted head strap in an MGS case, but UVGI did not cause any physical degradation. The fit test passing rate ranged from $90 \%$ to $100 \%$ and varied with the respirator model/decontamination method combination and donning trial. In general, microwave decontamination techniques, along with MHI and UVGI, did not cause significant changes in respirator fit [92]. A study by Viscusi et al. [119] reported that microwave oven irradiation caused melted samples for two FFR models. They believed that UVGI, ethylene oxide (EtO), and VHP were found to be the most promising decontamination methods [119]. Concerns regarding biocidal efficacy, 
respirator performance post decontamination, decontamination cost, and user safety have impeded adoption of reuse measures. However, in a work by Lore et al. [120], FFRs were examined post decontamination by viral culture, and all three decontamination methods (ultraviolet germicidal irradiation (UVGI), microwave-generated steam, and moist heat) were found to be effective, reducing virus load by $>4 \log$ median tissue culture infective dose. In terms of filter performance, all FFRs displayed $<5 \%$ penetration by 300 -nm particles. No profound reduction in filtration performance was measured in the FFRs tested following viral exposure and subsequent decontamination by the methods used. These findings indicate that, when properly implemented, these methods could effectively decontaminate $\mathrm{H} 5 \mathrm{~N} 1$ on the two FFR models tested and do not drastically affect their filtering function; however, other considerations may influence decisions to reuse FFRs [120]. The application of microwave decontamination techniques is not limited to facemasks but can be also extended to other PPE and also medical devices. Recently, research on the use of microwave decontamination confirmed that the hepatitis $C$ virus $(\mathrm{HCV})$ and the human immunodeficiency virus (HIV-1) have been deactivated through microwave irradiation, as a means of preventing viral transmission among people who inject drugs [121]. The exposure of $\mathrm{HCV}, \mathrm{HIV}$, and $\mathrm{HCV} / \mathrm{HIV}-1$ suspensions to microwave irradiation resulted in a significant reduction in their viral infectivity, confirming that this inactivation method is an effective, practical approach for the abrogation of HCV and HIV-1 infectivity in syringes and filters [121].

\section{Alternative Facemasks}

\subsection{Application of Photothermally and Photocatalytically Active Nanomaterials in Facemasks}

There are various nanomaterials (NMs) that exhibit remarkable photothermal and photocatalytic properties capable of inactivating microorganisms. Photocatalysts typically induce oxidative stress on microorganisms by producing reactive oxygen species (ROS) via light-catalyzed redox reactions, whereas photothermal properties allow local temperature increases leading to the inactivation of microorganisms [20,122-124]. Silver nanoparticles (Ag NPs) [125], copper oxide $\left(\mathrm{Cu}_{2} \mathrm{O}\right.$ and $\left.\mathrm{CuO}\right)$ [126], and titanium dioxide $\left(\mathrm{TiO}_{2}\right)$ [127] have already been reported in the past decades as possessing antimicrobial properties. They have been counted as an effective antimicrobial agent due to their low toxicity towards humans, high surface area per unit mass, and therefore, were incorporated into various filters [20,128-130]. The proposed mechanisms for their inactivation of microorganisms include the disruption of cell membrane metabolism via NM penetration or photocatalytic effect via ROS generation. Many antimicrobial nanoparticle coatings on protective equipment, such as masks, are being developed with antimicrobial activity that can automatically destroy or inactivate infectious microbes, thus reducing the risk of contamination due to their photocatalytic activity [20]. For this reason, a study was conducted on respiratory masks coated with an antimicrobial mixture of silver nitrate $\left(\mathrm{AgNO}_{3}\right)$ and $\mathrm{TiO}_{2}$ and tested against two types of bacteria: namely, Escherichia coli (E. coli) and Staphylococcus aureus (S. aureus). As a result, the coated masks showed a 100\% reduction in bacterial growth after $48 \mathrm{~h}[125,130]$. In addition to this, masks with a surface $\mathrm{TiO}_{2}$ apatite layer on the outer nonwoven fabric layer have shown good filtration and photocatalytic activity [131,132]. Hiragond et al. studied the enhanced antibacterial property of commercially available masks by coating them with Ag nanoparticles at different concentrations and then obtained the best Ag concentration for these masks. They also demonstrated that Ag NPs crossed plasma membranes as well as the lipid bilayer and entered into cytoplasm, leading to bacterial-cell destruction $[130,133,134]$. Since copper oxide is believed to possess potential antiviral and antibacterial properties, a novel anti-influenza copper oxide respiratory facemask was fabricated to protect against viral droplets. Copper nanoparticles are strong microbicides for a broad spectrum of microorganisms [20,135]. Recently, they demonstrated excellent performance against the 2019 coronavirus (COVID-19) [20,58,135,136]. The disinfection of masks exposed to COVID-19 is such a crucial issue, as the SARS-CoV-2 virus can remain infectious on the outer layer of a surgical mask for up to 6 days [20,137]. Even 
though the filtration efficiency of both the control and the copper oxide coated facemasks were found to be the same for human influenza A virus (H1N1) and avian influenza virus (H9N2) under simulated breathing conditions, the coated masks showed better activity against both of the viruses $[126,130]$. Along with metal NMs, it has been demonstrated that graphene, the most known two-dimensional (2D) NM, is also one of these antimicrobial agents $[20,138]$. Graphene with light absorbance capability, good viral inhibition capacity, and large surface area can destroy microorganisms photothermally [20,139-141]. Broad-spectrum antivirals such as heparin, heparin-like drugs, and sulfate-rich polymers simulate the sugars of the cell surfaces responsible for viral attachment, such as heparan sulfate (HS) $[139,142,143]$. Graphene increases the surface temperature in the near-infrared region (NIR) with the advantage of its large surface area, which provides a favorable ligand contact area to adsorb negatively charged sulfates. These sulfates can then interact with the positively charged residues of virions to block microorganisms [139,144-146]. Similarly, graphene derivatives such as graphene oxide (GO) and reduced $\mathrm{GO}(\mathrm{rGO})$ can inhibit microorganisms under light irradiation [139]. The antiviral activity of GO and GO-Ag was studied against feline coronavirus (FCoV) with an envelope and infectious bursal disease virus (IBDV) without an envelope. This study showed that GO-Ag inhibited both FCoV and IBDV due to the synergistic effect of GO sheets and Ag particles contributing to the antiviral activity. The positively charged lipid membrane was uniquely adsorbed by the GO to destroy the membrane $[139,147]$. Derivatives of graphene have also showed antiviral activity against African swine fever virus, orthopoxvirus, and herpesvirus strains. The interactions between rGO-sulfated derivatives and viruses were found to be dependent on the sulfation degree and polymer density. A higher degree of sulfation and smaller sheet size improved the antiviral effect on herpesvirus $[139,146,148]$. Additionally, they were exploited as drug delivery systems for antiviral compounds such as reverse transcriptase inhibitors conjugated with graphene quantum dots to treat HIV [149] and hypericin-GO against reovirus [150]. Furthermore, graphene is considered a potent immunomodulator, and GO-silver nanocomposites can facilitate the production of natural antiviral defenses (interferon- $\alpha$ and IFN stimulating genes) [86]. Besides this information, graphene and its derivatives have been reported to have a superhydrophobicity effect on material surfaces, meaning that they can also be used in textiles as filters to control the epidemiological spreading of SARS-CoV-2 [20,139]. Graphene filters capture particulates that cause diseases and block them, decreasing the transmission of nosocomial infections $[139,141]$. These blocked particulates on the filter are not able to proliferate and are destroyed by increasing the filters' temperature over $300{ }^{\circ} \mathrm{C}$ [139]. In addition to graphene filters, GO films could be used to create breathable barrier layers in facemasks because of their outstanding superhydrophobic and photothermal performance. Facemasks are highly useful as PPE protection when the surface layer is hydrophobic and dry $[139,151]$. This surface property prevents microorganism penetration into the layers and increases particulate matter (PM) removal efficiency. Li et al. [152] reported a unique method to deposit few-layer-graphene onto a low-melting temperature nonwoven mask, which could endow commercial surgical masks with excellent self-cleaning and photothermal properties. In the same study, it was shown that the superhydrophobic surface of graphene or GO-coated masks could effectively exclude incoming aqueous droplets and that the coated mask surface could be self-sterilized under sunlight illumination, reaching a temperature of up to $80^{\circ} \mathrm{C}$ rapidly (SARS-CoV-2 is deactivated by heat treatments of $65^{\circ} \mathrm{C}$ or higher [152-154]). This method is good for green and environmental protection for the development of reusable masks [154]. Lin et al. demonstrated that graphene nanosheet-embedded carbon (GNEC) fragments can be uniformly and randomly distributed on a pristine mask. The GNEC mask showed promising performance such as excellent hydrophobic ability, 100\% filtration efficiency, and a high photosterilization performance [155]. Overall, it appears that nonwoven masks and pristine masks have some limitations owing to their insufficient hydrophobic surfaces [156,157], low melting temperatures that are usually lower than $130^{\circ} \mathrm{C}$ [158], and difficulty recycling [152]. Accordingly, pristine masks could be coated with metal-based NMs such as 
$\mathrm{TiO}_{2}, \mathrm{AgNO}_{3}$, and graphene (and its derivatives) to overcome these issues. The usage of these nanomaterials could also improve potential environmental problems, such as the high production and disposal rates of these masks [20]. Masks coated with $\mathrm{Ag}$ or $\mathrm{TiO}_{2}$ nanoparticles, and graphene-based materials, have been studied extensively in order to confer their antimicrobial activity. With the recent developments in the field of 2D nanomaterials, masks coated with novel photocatalytically and photothermally active materials may find their place in the fight against COVID-19 and future viral pandemics [159-161].

\subsection{The Development of Sustainable Facemasks}

As an alternative to current strategies and feedstock for making facemasks, the development of sustainable facemasks by focusing on a circular economy, environmentally sustainable resources, and manufacturing techniques stands as a promising approach for addressing PPE concerns during a pandemic. Spinning techniques, such as wet spinning, electrospinning, and melt spinning, are being used to develop different types of yarns, fibers, and membranes [162-167]. The electrospinning technique uses a high voltage to produce an interconnected web of small fibers (10-500 $\mathrm{nm}$ in diameter) from a polymer dope. This technique provides opportunities for the fabrication of fibrous materials from a variety of polymers $[165,166,168,169]$. Depending on the type of polymer being used, physiochemical and micromechanical properties, such as strength, surface area, weight, and porosity, can be tuned. It has been reported that much smaller fiber diameters and increased surface areas are achievable through electrospinning techniques, as compared with many currently available textile fibers $[168,170]$. Synthetic polymers have been used extensively to produce various types of micro and nanofibers. In addition to the use of polypropylene and polyethylene, reports have shown the successful use of Poly (vinyl alcohol) (PVA), Poly (ethylene oxide) (PEO), Poly(lactic acid) (PLA) Polyvinylpyrrolidone (PVP), bioactive glass, and Poly ( $\varepsilon$-caprolactone) (PCL) as synthetic polymers for the development of bioactive, electrospun nanofibers [171,172]. Some works have been performed on the development of a PLA that is biodegradable and biocompatible for bioactive fiber manufacturing, tissue engineering, regenerative medicine, and engineering soft tissues [171]. In terms of natural polymers, chitan, starch, cinnamon oil, whey protein, chitosan, thermoplastic carboxymethyl cellulose (TCMC), lignin, silk, and chitin have been reported for their development towards bioactive nanofibers and filtration applications [173-180].

To provide multifunctionality to facemasks, different approaches have been employed, including (i) enhancing the filtration capacity of the facemask material and (ii) imparting additional functions and properties into the facemasks. As mentioned in the previous section, nanoparticle coatings have been used to protect against infectious agents, including silver nanoparticles and compounds, copper nanoparticles, titanium dioxide $\left(\mathrm{TiO}_{2}\right)$, zinc oxide $(\mathrm{ZnO})$, and aluminum/aluminum oxide $\left(\mathrm{Al}_{2} \mathrm{O}_{3}\right)$ [125,181-186]. It was reported that the combination of the metallic nanoparticles and colloids with other nanomaterials, such as CNTs and graphene, can improve the antimicrobial qualities of facemasks [187-190]. Moreover, it is believed that sustainable resources, such as biochar from low-cost feedstocks and/or waste resources, could perform well in water treatment and pollution remediation, including the sorption of pharmaceuticals and personal care products (PPCPs) [191-195]. It is believed that licorice nanofibers can be assembled for increased protection against COVID-19 and other similar viruses [196]. Antiviral facemasks have been fabricated via electrospinning with licorice root extract on the facemasks, which has antimicrobial properties due to glycyrrhetinic acid (GA) and glycyrrhizin (GL) [196] (Figure 8). It was observed that microfibers containing PVA and licorice root extract, in the range of 15-30 $\mu \mathrm{m}$ in diameter with random porosity/orientation, were suitable to capture the virus. Nanofibers could deactivate the virus by releasing GL and GA via contact. To form multifunctional membranes, organic-inorganic hybrid structures, based on bacterial cellulose (BC), have been developed that contain photoactive $\left(\mathrm{TiO}_{2}\right)$ and antibacterial $(\mathrm{Ag})$ components possessing photocatalytic, self-cleaning, and UV-shielding properties (due to $\mathrm{TiO}_{2}$ ), as well as antibacterial performance [197]. Synthesized photoactive $\mathrm{BC}-\mathrm{SiO}_{2}-\mathrm{TiO}_{2}$ membranes 
showed excellent $\mathrm{TiO}_{2}$-loading, dependent photocatalytic/self-cleaning, and reasonable antibacterial activity against five different bacterial strains under dark conditions. This has made it a very promising candidate for self-cleaning/antibacterial surfaces, filters, and facemasks that could be easily disinfected under UV irradiation from a lamp or natural sunlight [197].

Zeolitic imidazolate (ZIF-8) metal organic frameworks have been used for highly efficient PM2.5 capture due to their excellent chemical and thermal stability. ZIF-8-modified soluble polyimide (PI) nanofibrous membranes present a high PM2.5 filtration efficiency (up to $96.6 \pm 2.9 \%$ ), superior thermal stability (up to $300^{\circ} \mathrm{C}$ ), good transmittance, excellent mechanical properties, and low pressure drop, making them a suitable candidate for PM2.5 capture, especially in harsh conditions [198,199].

As a creative approach to multifunctionality in facemask development, a triboelectric nanogenerators (TENG)-formed multilayer filter has been suggested, in which the inner three layers act as a triboelectric (TE) filter and the outer one as an electrocution layer (EL) [200]. Viral particles would experience a mild shock in the EL due to the electric field produced at the electrocution layer by contact electrification. Polyvinylchloride (PVC)nylon, polypropylene (PP)-polyurethane (PU), latex rubber-PU, and polyimide (PI)-nylon have been examined as triboelectric materials to establish the efficacy of the mask design. The force exerted on the triboelectric filter materials could produce sufficient electric power to activate the EL. The proposed mask can be self-powering: charged through the breathing cycles and/or talking or other relevant facial gestures [200].(see Figure 8) The accumulated charge could produce a sufficient electric field to deactivate the exterior proteins of the charged viral particles via electrocution.
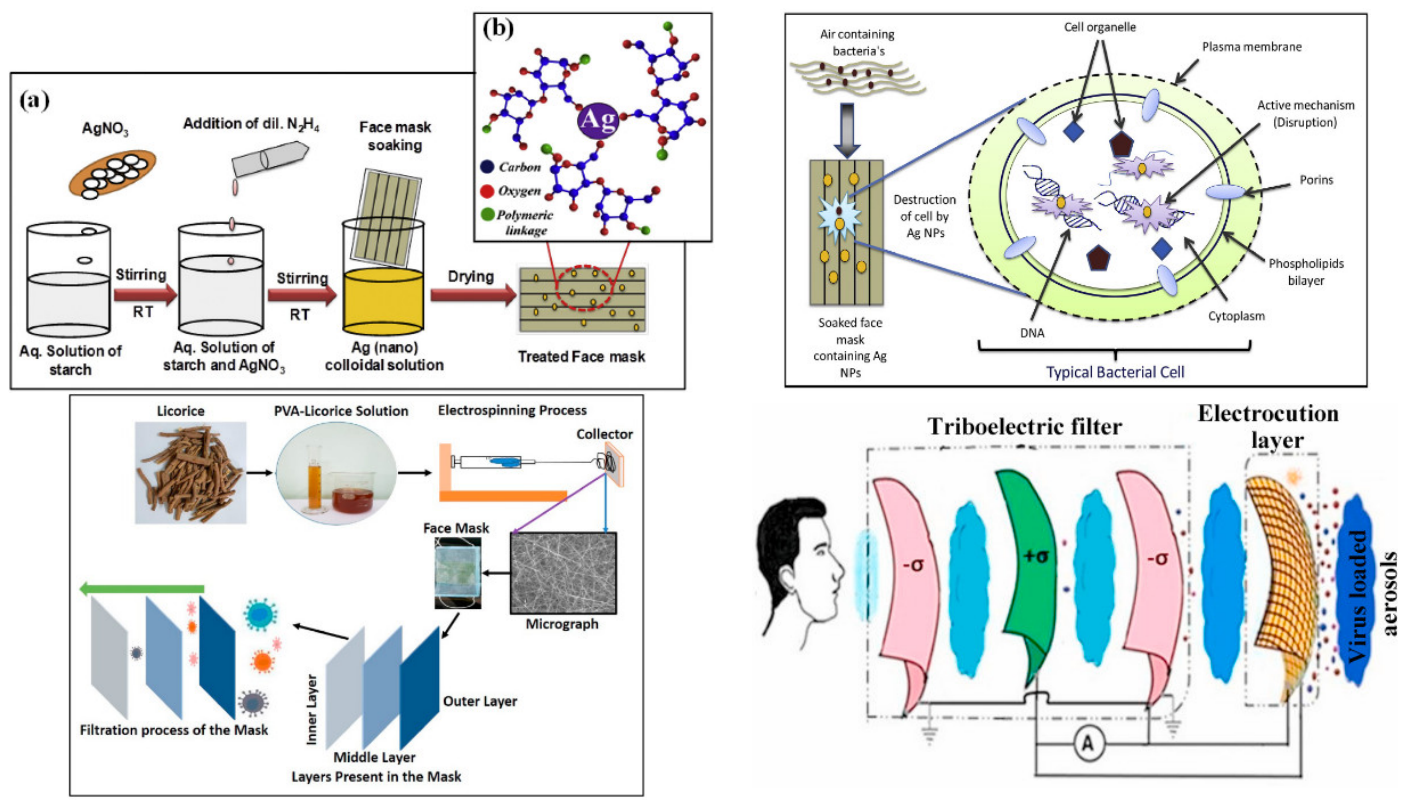

Figure 8. (a) Schematic representation of synthesis of colloidal Ag (nano) solution and its treatment with facemask (b) starch capped Ag nanoparticles over the mask. Representative dual antimicrobial mechanism of Ag nanoparticles embedded facemask [133]; fabrication of an antiviral facemask using licorice root extract/PVA [196]; schematic representation of the proposed triboelectric multilayers comprising a self-powered mask. Inner three layers (from face side) are acting as a TE filter and outer layer is the EL made with a conducting mesh [200].

Researchers at the university of British Columbia presented a new compostable facemask that was produced from local wood fibers such as pine, spruce, and cedar [201]. In another sustainable solution, Sum Studio provided an alternative facemask fabricated out of bacterial cellulose - a by-product of a bacteria called xylinum acetobacter [202]. The process of facemask fabrication takes a couple of weeks, but unlike other commercial facemasks, it is 
completely transparent, which makes it appealing for design-conscious customers, as well as being sustainable due to its bio-based feedstock. In another attempt, EPFL's scientists working with Empa have developed a fully transparent and eco-friendly facemask with precise porosity that will be produced on an industrial scale as early as 2021 [203]. The mindset shift in the facemask feedstocks is not limited to materials discussed in this paper, and even coffee has been tested as a sustainable resource for facemask use. ShoeX, whom introduced this reusable facemask made from coffee, claims that the fabricated facemask is antimicrobial with an AATCC 100 certification [204]. However, it is very important to note that most of the proposed ideas are still very much at the laboratory scale and need to be scaled up and fully tested/characterized, and people's preferences and acceptance in society need to be gauged further. For the effect of replacing current facemasks with biodegradable facemasks, there is a need to perform very systematic research whenever the full mass-scale fabrication of biodegradable facemasks is available.

\section{Valorization of the Facemask}

The global valorization rate of plastic waste is low, and potential practices for waste management related to the waste valorization of discarded facemasks as the major type of waste during the COVID-19 pandemic can be a very promising study for further policymaking around sustainability and circular economy in a field [89]. Different techniques can be used for the repurposing of facemasks, including carbonization, pyrolysis, catalytic deformation, and high-solids anaerobic digestion. The product of the mentioned techniques with the use of facemasks as a feedstock can be fuel-range hydrocarbons, building materials, soil stabilization, value-added aromatics (BTEX), adsorbent-dye carriers, fuel, and cathode and anode electrodes for supercapacitors $[88,89,205]$. The findings from different valorization studies provide alternative options for tackling waste PPE, especially facemasks [89]. Figure 9 provides the schematic of the procedure that can be followed for the valorization of PPE, including facemasks during/post pandemic as an alternative approach [89,206].

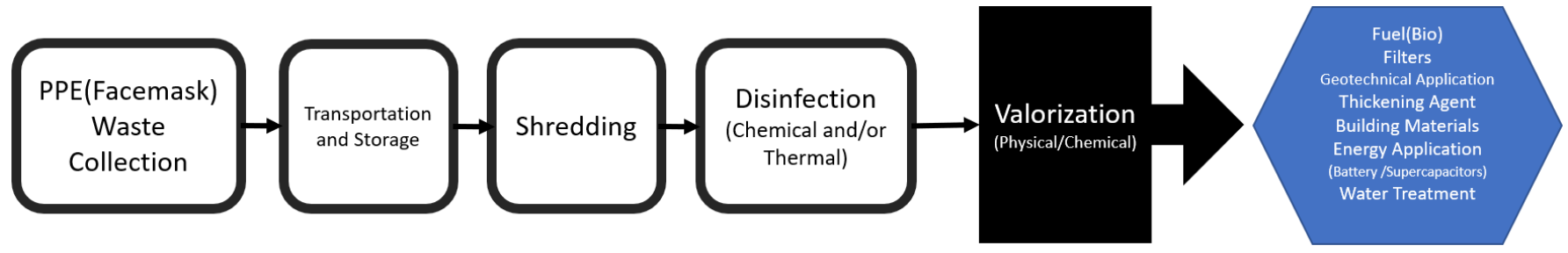

Figure 9. Valorization of PPE including facemask as an alternative approach: reproduced from Refs. [89,206].

\section{Concluding Remarks}

The market of facemasks was overwhelmed and shocked by the sudden increase in demand during the global pandemic outbreak of COVID-19. The global increase in facemask use was also caused by government policies and health experts' advice, which made mask use compulsory in many countries around the world. Improved access to highquality, reliable, and protective facemask materials constitutes one of the main challenges. The second main challenge is their proper disposal. It has been reported that reusable cloth facemasks have been reused without washing or that disposable facemasks have been washed and re-sold to the public [207]. Although the utilization of facemasks has been widely advocated to prevent the spread of disease, facemasks stand to be directly related to several environmental challenges. Their generated waste is a source of microplastics and is currently being disposed of in the environment through landfills, dumpsites, and incineration, though some are making their way into oceans and freshwater supplies. Apart from their increasing ecological burden, the growing amount of accumulated microplastics in the environment may become a further source for disease outbreak. To solve some of the preceding problems, governments and policymakers should attempt to devise proper 
solutions. In this context, it has become essential to address the emerging challenges by developing a new class of facemasks that are effective against the virus while being biodegradable and sustainable. The proposed materials for future facemasks are largely natural or biodegradable polymers. This paper concludes that a vast number of natural and/or biodegradable polymers can be successfully used for manufacturing facemasks, such as wood-based polymers, chitosan, and other biodegradable synthetic polymers. However, it is worth noting that the cost analysis of alternative facemasks needs to be fully discovered with the development of comprehensive research works in order to make or claim that this strategy is sustainable.

Funding: This research received no external funding.

Institutional Review Board Statement: Not applicable.

Informed Consent Statement: Not applicable.

Data Availability Statement: Not applicable.

Conflicts of Interest: The authors declare no conflict of interest.

\section{References}

1. Pietsch, F.; O’Neill, A.; Ivask, A.; Jenssen, H.; Inkinen, J.; Kahru, A.; Ahonen, M.; Schreiber, F. Selection of resistance by antimicrobial coatings in the healthcare setting. J. Hosp. Infect. 2020, 106, 115-125. [CrossRef] [PubMed]

2. Chen, Z.; Zhang, W.; Lu, Y.; Guo, C.; Guo, Z.; Liao, C.; Zhang, X.; Zhang, Y.; Han, X.; Li, Q. From SARS-CoV to Wuhan 2019-nCoV outbreak: Similarity of early epidemic and prediction of future trends. Cell Host Microbe 2020. D-20-00063. [CrossRef]

3. Chauhan, D.S.; Prasad, R.; Srivastava, R.; Jaggi, M.; Chauhan, S.C.; Yallapu, M.M. Comprehensive Review on Current Interventions, Diagnostic, and Nanotechnology Perspectives against SARS-CoV-2. Bioconjg. Chem. 2020, 31, 2021-2045. [CrossRef] [PubMed]

4. Qing, E.; Gallagher, T. SARS Coronavirus Redux. Trends Immunol. 2020, 41, 271-273. [CrossRef] [PubMed]

5. Gil, C.; Ginex, T.; Maestro, I.; Nozal, V.; Barrado-Gil, L.; Cuesta-Geijo, M.Á.; Urquiza, J.; Ramírez, D.; Alonso, C.; Campillo, N.E.; et al. COVID-19: Drug Targets and Potential Treatments. J. Med. Chem. 2020, 63, 12359-12386. [CrossRef]

6. Anti-viral Coatings: Protecting Your Health or the Durability of the Item? Focus Powder Coat. 2020, 2020, 1-10. [CrossRef]

7. Das, O.; Neisiany, R.E.; Capezza, A.J.; Hedenqvist, M.S.; Försth, M.; Xu, Q.; Jiang, L.; Ji, D.; Ramakrishna, S. The need for fully bio-based facemasks to counter coronavirus outbreaks: A perspective. Sci. Total Environ. 2020, 736, 139611. [CrossRef]

8. Zangmeister, C.D.; Radney, J.G.; Vicenzi, E.P.; Weaver, J.L. Filtration efficiencies of nanoscale aerosol by cloth mask materials used to slow the spread of SARS-CoV-2. ACS Nano 2020, 14, 9188-9200. [CrossRef]

9. Prather, K.A.; Wang, C.C.; Schooley, R. Reducing transmission of SARS-CoV-2. Science 2020, 368, 1422-1424. [CrossRef]

10. Prata, J.C.; Silva, A.P.; Walker, T.R.; Duarte, A.C.; Rocha-Santos, T. COVID-19 Pandemic Repercussions on the Use and Management of Plastics. Environ. Sci. Technol. 2020, 54, 7760-7765. [CrossRef] [PubMed]

11. Czigány, T.; Ronkay, F. Editorial corner-a personal view. eXPRESS Polym. Lett. 2020, 14, 510-511.

12. Ji, D.; Fan, L.; Li, X.; Ramakrishna, S. Addressing the worldwide shortages of face masks. BMC Mater. 2020, 2, 9. [CrossRef]

13. Institute of Medicine. Reusability of Facemasks during an Influenza Pandemic. In B.o.H.S.P. Committee on the Development of Reusable Facemasks for Use during an Influenza Pandemic; The National Academies Press: Washington, DC, USA, 2006.

14. Chan, K.H.; Yuen, K.-Y. COVID-19 epidemic: Disentangling the re-emerging controversy about medical facemasks from an epidemiological perspective. Int. J. Epidemiol. 2020, 49, 1063-1066. [CrossRef]

15. Kadam, V.V.; Wang, L.; Padhye, R. Electrospun nanofibre materials to filter air pollutants-A review. J. Ind. Text. 2018, 47, 2253-2280. [CrossRef]

16. Zhu, M.; Han, J.; Wang, F.; Shao, W.; Xiong, R.; Zhang, Q.; Pan, H.; Yang, Y.; Samal, S.K.; Zhang, F.; et al. Electrospun Nanofibers Membranes for Effective Air Filtration. Macromol. Mater. Eng. 2017, 302, 1600353. [CrossRef]

17. Yang, C. Aerosol Filtration Application Using Fibrous Media-An Industrial Perspective. Chin. J. Chem. Eng. 2012, 20, 1-9. [CrossRef]

18. Kutter, J.S.; Spronken, M.I.; Fraaij, P.L.; Fouchier, R.A.; Herfst, S. Transmission routes of respiratory viruses among humans. Curr. Opin. Virol. 2018, 28, 142-151. [CrossRef]

19. Boone, S.A.; Gerba, C.P. Significance of Fomites in the Spread of Respiratory and Enteric Viral Disease. Appl. Environ. Microbiol. 2007, 73, 1687-1696. [CrossRef] [PubMed]

20. Chua, M.H.; Cheng, W.; Goh, S.S.; Kong, J.; Li, B.; Lim, J.Y.C.; Mao, L.; Wang, S.; Xue, K.; Yang, L.; et al. Face Masks in the New COVID-19 Normal: Materials, Testing, and Perspectives. Research 2020, 2020, 7286735. [CrossRef]

21. Wei, J.; Li, Y. Airborne spread of infectious agents in the indoor environment. Am. J. Infect. Control 2016, 44, S102-S108. [CrossRef] [PubMed]

22. Knight, V. Viruses as agents of airborne contagion. Ann. N. Y. Acad. Sci. 1980, 353, 147-156. [CrossRef] 
23. Dbouk, T.; Drikakis, D. On respiratory droplets and face masks. Phys. Fluids 2020, 32, 063303. [CrossRef]

24. Anfinrud, P.; Stadnytskyi, V.; Bax, C.E.; Bax, A. Visualizing Speech-Generated Oral Fluid Droplets with Laser Light Scattering. N. Engl. J. Med. 2020, 382, 2061-2063. [CrossRef]

25. Kähler, C.J.; Hain, R. Fundamental protective mechanisms of face masks against droplet infections. J. Aerosol Sci. 2020, $148,105617$. [CrossRef]

26. Davies, A.; Thompson, K.; Giri, K.; Kafatos, G.; Walker, J.; Bennett, A. Testing the efficacy of homemade masks: Would they protect in an influenza pandemic? Disaster Med. Public Health Prep. 2013, 7, 413-418. [CrossRef] [PubMed]

27. Konda, A.; Prakash, A.; Moss, G.A.; Schmoldt, M.; Grant, G.D.; Guha, S. Aerosol Filtration Efficiency of Common Fabrics Used in Respiratory Cloth Masks. ACS Nano 2020, 14, 6339-6347. [CrossRef]

28. Hancock, J.N.; Plumley, M.J.; Schilling, K.; Sheets, D.; Wilen, L. Comment on “Aerosol Filtration Efficiency of Common Fabrics Used in Respiratory Cloth Masks". ACS Nano 2020, 14, 10758-10763. [CrossRef] [PubMed]

29. World Health Organization. Advice on the Use of Masks in the Context of COVID-19: Interim Guidance, 5 June 2020; World Health Organization: Geneva, Switzerland, 2020.

30. Li, L.; Zhao, X.; Li, Z.; Song, K. COVID-19: Performance study of microplastic inhalation risk posed by wearing masks. J. Hazard. Mater. 2020, 411, 124955. [CrossRef]

31. Fadare, O.O.; Okoffo, E.D. Covid-19 face masks: A potential source of microplastic fibers in the environment. Sci. Total Environ. 2020, 737, 140279. [CrossRef] [PubMed]

32. Silva, A.L.P.; Prata, J.C.; Walker, T.R.; Duarte, A.C.; Ouyang, W.; Barcelò, D.; Rocha-Santos, T. Increased plastic pollution due to COVID-19 pandemic: Challenges and recommendations. Chem. Eng. J. 2021, 405, 126683. [CrossRef]

33. Aragaw, T.A. Surgical face masks as a potential source for microplastic pollution in the COVID-19 scenario. Mar. Pollut. Bull. 2020, 159, 111517. [CrossRef] [PubMed]

34. Ardusso, M.; Forero-López, A.; Buzzi, N.; Spetter, C.; Fernández-Severini, M. COVID-19 pandemic repercussions on plastic and antiviral polymeric textile causing pollution on beaches and coasts of South America. Sci. Total Environ. 2021, 763, 144365. [CrossRef]

35. Abbasi, S.A.; Khalil, A.B.; Arslan, M. Extensive use of face masks during COVID-19 pandemic: (micro-)plastic pollution and potential health concerns in the Arabian Peninsula. Saudi J. Biol. Sci. 2020, 27, 3181-3186. [CrossRef] [PubMed]

36. Ormaza-González, F.; Castro-Rodas, D. COVID-19 Impacts on Beaches and Coastal Water Pollution: Management Proposals Post-Pandemic. Front. Mar. Sci. 2020, 8, 2020060186. [CrossRef]

37. Shirvanimoghaddam, K.; Abolhasani, M.M.; Polisetti, B.; Naebe, M. Periodical patterning of a fully tailored nanocarbon on CNT for fabrication of thermoplastic composites. Compos. Part A Appl. Sci. Manuf. 2018, 107, 304-314. [CrossRef]

38. Shirvanimoghaddam, K.; Polisetti, B.; Dasari, A.; Yang, J.; Ramakrishna, S.; Naebe, M. Thermomechanical performance of cheetah skin carbon nanotube embedded composite: Isothermal and non-isothermal investigation. Polymer 2018, 145, 294-309. [CrossRef]

39. Balaji, K.V.; Shirvanimoghaddam, K.; Rajan, G.S.; Ellis, A.V.; Naebe, M. Surface treatment of Basalt fiber for use in automotive composites. Mater. Today Chem. 2020, 17, 100334. [CrossRef]

40. Shirvanimoghaddam, K.; Balaji, K.; Yadav, R.; Zabihi, O.; Ahmadi, M.; Adetunji, P.; Naebe, M. Balancing the toughness and strength in polypropylene composites. Compos. Part B Eng. 2021, 223, 109121. [CrossRef]

41. Rubio-Romero, J.C.; del Carmen Pardo-Ferreira, M.; Torrecilla-García, J.A.; Calero-Castro, S. Disposable masks: Disinfection and sterilization for reuse, and non-certified manufacturing, in the face of shortages during the COVID-19 pandemic. Saf. Sci. 2020, 129, 104830. [CrossRef]

42. Mammo, F.; Amoah, I.; Gani, K.; Pillay, L.; Ratha, S.; Bux, F.; Kumari, S. Microplastics in the environment: Interactions with microbes and chemical contaminants. Sci. Total Environ. 2020, 743, 140518. [CrossRef]

43. Gong, J.; Xie, P. Research progress in sources, analytical methods, eco-environmental effects, and control measures of microplastics. Chemosphere 2020, 254, 126790. [CrossRef] [PubMed]

44. Ragusa, A.; Svelato, A.; Santacroce, C.; Catalano, P.; Notarstefano, V.; Carnevali, O.; Papa, F.; Rongioletti, M.C.A.; Baiocco, F.; Draghi, S.; et al. Plasticenta: First evidence of microplastics in human placenta. Environ. Int. 2021, 146, 106274. [CrossRef]

45. Wang, J.; Shen, J.; Ye, D.; Yan, X.; Zhang, Y.; Yang, W.; Li, X.; Wang, J.; Zhang, L.; Pan, L. Disinfection technology of hospital wastes and wastewater: Suggestions for disinfection strategy during coronavirus Disease 2019 (COVID-19) pandemic in China. Environ. Pollut. 2020, 262, 114665. [CrossRef] [PubMed]

46. Bläsing, M.; Amelung, W. Plastics in soil: Analytical methods and possible sources. Sci. Total Environ. 2018, 612, 422-435. [CrossRef]

47. Zhou, Y.; Wang, J.; Zou, M.; Jia, Z.; Zhou, S.; Li, Y. Microplastics in soils: A review of methods, occurrence, fate, transport, ecological and environmental risks. Sci. Total Environ. 2020, 748, 141368. [CrossRef]

48. Ilyas, S.; Srivastava, R.R.; Kim, H. Disinfection technology and strategies for COVID-19 hospital and bio-medical waste management. Sci. Total Environ. 2020, 749, 141652. [CrossRef] [PubMed]

49. Vanapalli, K.R.; Sharma, H.B.; Ranjan, V.P.; Samal, B.; Bhattacharya, J.; Dubey, B.K.; Goel, S. Challenges and strategies for effective plastic waste management during and post COVID-19 pandemic. Sci. Total Environ. 2021, 750, 141514. [CrossRef]

50. Wilkinson, J.; Hooda, P.; Barker, J.; Barton, S.; Swinden, J. Occurrence, fate and transformation of emerging contaminants in water: An overarching review of the field. Environ. Pollut. 2017, 231, 954-970. [CrossRef] [PubMed] 
51. Miller, R.Z.; Watts, A.J.; Winslow, B.O.; Galloway, T.S.; Barrows, A.P. Mountains to the sea: River study of plastic and non-plastic microfiber pollution in the northeast USA. Mar. Pollut. Bull. 2017, 124, 245-251. [CrossRef]

52. Garcés-Ordóñez, O.; Castillo-Olaya, V.A.; Granados-Briceño, A.F.; García, L.M.B.; Díaz, L.F.E. Marine litter and microplastic pollution on mangrove soils of the Ciénaga Grande de Santa Marta, Colombian Caribbean. Mar. Pollut. Bull. 2019, 145, 455-462. [CrossRef]

53. Lima, A.R.A.; Barletta, M.; Costa, M.F. Seasonal distribution and interactions between plankton and microplastics in a tropical estuary. Estuar. Coast. Shelf Sci. 2015, 165, 213-225. [CrossRef]

54. Cole, M.; Lindeque, P.; Halsband, C.; Galloway, T.S. Microplastics as contaminants in the marine environment: A review. Mar. Pollut. Bull. 2011, 62, 2588-2597. [CrossRef]

55. Mendoza, L.M.R.; Karapanagioti, H.K.; Álvarez, N.R. Micro(nanoplastics) in the marine environment: Current knowledge and gaps. Curr. Opin. Environ. Sci. Health 2018, 1, 47-51. [CrossRef]

56. Mejjad, N.; Cherif, E.; Rodero, A.; Krawczyk, D.; El Kharraz, J.; Moumen, A.; Laqbaqbi, M.; Fekri, A. Disposal Behavior of Used Masks during the COVID-19 Pandemic in the Moroccan Community: Potential Environmental Impact. Int. J. Environ. Res. Public Health 2021, 18, 4382. [CrossRef] [PubMed]

57. Cherif, E.K.; Vodopivec, M.; Mejjad, N.; Da Silva, J.C.G.E.; Simonovič, S.; Boulaassal, H. COVID-19 Pandemic Consequences on Coastal Water Quality Using WST Sentinel-3 Data: Case of Tangier, Morocco. Water 2020, 12, 2638. [CrossRef]

58. Shirvanimoghaddam, K.; Akbari, M.K.; Yadav, R.; Al-Tamimi, A.K.; Naebe, M. Fight against COVID-19: The case of antiviral surfaces. APL Mater. 2021, 9, 031112. [CrossRef] [PubMed]

59. Sharma, H.B.; Vanapalli, K.R.; Cheela, V.S.; Ranjan, V.P.; Jaglan, A.K.; Dubey, B.; Goel, S.; Bhattacharya, J. Challenges, opportunities, and innovations for effective solid waste management during and post COVID-19 pandemic. Resour. Conserv. Recycl. 2020, 162, 105052. [CrossRef]

60. Bowley, J.; Baker-Austin, C.; Porter, A.; Hartnell, R.; Lewis, C. Oceanic Hitchhikers - Assessing Pathogen Risks from Marine Microplastic. Trends Microbiol. 2021, 29, 107-116. [CrossRef]

61. Dong, H.; Chen, Y.; Wang, J.; Zhang, Y.; Zhang, P.; Li, X.; Zou, J.; Zhou, A. Interactions of microplastics and antibiotic resistance genes and their effects on the aquaculture environments. J. Hazard. Mater. 2021, 403, 123961. [CrossRef]

62. Brennecke, D.; Duarte, B.; Paiva, F.; Caçador, I.; Clode, J.C. Microplastics as vector for heavy metal contamination from the marine environment. Estuar. Coast. Shelf Sci. 2016, 178, 189-195. [CrossRef]

63. Gago, J.; Carretero, O.; Filgueiras, A.V.; Viñas, L. Synthetic microfibers in the marine environment: A review on their occurrence in seawater and sediments. Mar. Pollut. Bull. 2018, 127, 365-376. [CrossRef]

64. Revel, M.; Chatel, A.; Mouneyrac, C. Micro(nano)plastics: A threat to human health? Curr. Opin. Environ. Sci. Health 2018, 1, 17-23. [CrossRef]

65. Cai, M.; He, H.; Liu, M.; Li, S.; Tang, G.; Wang, W.; Huang, P.; Wei, G.; Lin, Y.; Chen, B.; et al. Lost but can't be neglected: Huge quantities of small microplastics hide in the South China Sea. Sci. Total Environ. 2018, 633, 1206-1216. [CrossRef] [PubMed]

66. Fernández Severini, M.D.; Buzzi, N.S.; Forero López, A.D.; Colombo, C.V.; Chatelain Sartor, G.L.; Rimondino, G.N.; Truchet, D.M. Chemical composition and abundance of microplastics in the muscle of commercial shrimp Pleoticus muelleri at an impacted coastal environment (Southwestern Atlantic). Mar. Pollut. Bull. 2020, 161, 111700. [CrossRef] [PubMed]

67. López, A.F.; Truchet, D.M.; Rimondino, G.; Maisano, L.; Spetter, C.; Buzzi, N.; Nazzarro, M.; Malanca, F.; Furlong, O.; Severini, M.F. Microplastics and suspended particles in a strongly impacted coastal environment: Composition, abundance, surface texture, and interaction with metal ions. Sci. Total Environ. 2021, 754, 142413. [CrossRef] [PubMed]

68. Gunasekaran, D.; Chandrasekaran, N.; Jenkins, D.; Mukherjee, A. Plain polystyrene microplastics reduce the toxic effects of ZnO particles on marine microalgae Dunaliella salina. J. Environ. Chem. Eng. 2020, 8, 104250. [CrossRef]

69. Estrela, F.N.; Guimarães, A.T.B.; Silva, F.G.; da Luz, T.M.; Silva, A.M.; Pereira, P.S.; Malafaia, G. Effects of polystyrene nanoplastics on Ctenopharyngodon idella (grass carp) after individual and combined exposure with zinc oxide nanoparticles. J. Hazard. Mater. 2021, 403, 123879. [CrossRef]

70. Yong, C.Q.Y.; Valiyaveettil, S.; Tang, B.L. Toxicity of Microplastics and Nanoplastics in Mammalian Systems. Int. J. Environ. Res. Public Health 2020, 17, 1509. [CrossRef]

71. Lin, J.; Yan, D.; Fu, J.; Chen, Y.; Ou, H. Ultraviolet-C and vacuum ultraviolet inducing surface degradation of microplastics. Water Res. 2020, 186, 116360. [CrossRef]

72. Bilgin, M.; Yurtsever, M.; Karadagli, F. Microplastic removal by aerated grit chambers versus settling tanks of a municipal wastewater treatment plant. J. Water Process. Eng. 2020, 38, 101604. [CrossRef]

73. Rahman, A.; Sarkar, A.; Yadav, O.P.; Achari, G.; Slobodnik, J. Potential human health risks due to environmental exposure to nano- and microplastics and knowledge gaps: A scoping review. Sci. Total Environ. 2021, 757, 143872. [CrossRef]

74. Turan, N.B.; Erkan, H.S.; Engin, G.O.; Bilgili, M.S. Nanoparticles in the aquatic environment: Usage, properties, transformation and toxicity-A review. Process Saf. Environ. Prot. 2019, 130, 238-249. [CrossRef]

75. Balbi, T.; Camisassi, G.; Montagna, M.; Fabbri, R.; Franzellitti, S.; Carbone, C.; Dawson, K.A.; Canesi, L. Impact of cationic polystyrene nanoparticles (PS-NH2) on early embryo development of Mytilus galloprovincialis: Effects on shell formation. Chemosphere 2017, 186, 1-9. [CrossRef] [PubMed]

76. Blettler, M.C.M.; Ulla, M.A.; Rabuffetti, A.P.; Garello, N. Plastic pollution in freshwater ecosystems: Macro-, meso-, and microplastic debris in a floodplain lake. Environ. Monit. Assess. 2017, 189, 581. [CrossRef] 
77. Kang, P.; Ji, B.; Zhao, Y.; Wei, T. How can we trace microplastics in wastewater treatment plants: A review of the current knowledge on their analysis approaches. Sci. Total Environ. 2020, 745, 140943. [CrossRef] [PubMed]

78. Enfrin, M.; Dumée, L.F.; Lee, J. Nano/microplastics in water and wastewater treatment processes-Origin, impact and potential solutions. Water Res. 2019, 161, 621-638. [CrossRef]

79. Talvitie, J.; Mikola, A.; Setälä, O.; Heinonen, M.; Koistinen, A. How well is microlitter purified from wastewater?-A detailed study on the stepwise removal of microlitter in a tertiary level wastewater treatment plant. Water Res. 2017, 109, 164-172. [CrossRef] [PubMed]

80. Fu, S.-F.; Ding, J.-N.; Zhang, Y.; Li, Y.-F.; Zhu, R.; Yuan, X.-Z.; Zou, H. Exposure to polystyrene nanoplastic leads to inhibition of anaerobic digestion system. Sci. Total Environ. 2018, 625, 64-70. [CrossRef] [PubMed]

81. Severini, M.D.F.; Villagran, D.M.; Buzzi, N.S.; Sartor, G.C. Microplastics in oysters (Crassostrea gigas) and water at the Bahía Blanca Estuary (Southwestern Atlantic): An emerging issue of global concern. Reg. Stud. Mar. Sci. 2019, 32, 100829. [CrossRef]

82. Silva, P.M.; Nanny, M.A. Impact of Microplastic Fibers from the Degradation of Nonwoven Synthetic Textiles to the Magdalena River Water Column and River Sediments by the City of Neiva, Huila (Colombia). Water 2020, 12, 1210. [CrossRef]

83. Alves, V.E.; Figueiredo, G.M. Microplastic in the sediments of a highly eutrophic tropical estuary. Mar. Pollut. Bull. 2019, 146, 326-335. [CrossRef] [PubMed]

84. Takdastan, A.; Niari, M.H.; Babaei, A.; Dobaradaran, S.; Jorfi, S.; Ahmadi, M. Occurrence and distribution of microplastic particles and the concentration of Di 2-ethyl hexyl phthalate (DEHP) in microplastics and wastewater in the wastewater treatment plant. $J$. Environ. Manag. 2021, 280, 111851. [CrossRef] [PubMed]

85. Schwan, J.; Alva, T.R.; Nava, G.; Rodriguez, C.B.; Dunn, Z.S.; Chartron, J.W.; Morgan, J.; Wang, P.; Mangolini, L. Efficient facemask decontamination via forced ozone convection. Sci. Rep. 2021, 11, 12263. [CrossRef]

86. Du, T.; Lu, J.; Liu, L.; Dong, N.; Fang, L.; Xiao, S.; Han, H. Antiviral Activity of Graphene Oxide-Silver Nanocomposites by Preventing Viral Entry and Activation of the Antiviral Innate Immune Response. ACS Appl. Bio Mater. 2018, 1, 1286-1293. [CrossRef]

87. Li, D.T.S.; Samaranayake, L.P.; Leung, Y.Y.; Neelakantan, P. Facial protection in the era of COVID-19: A narrative review. Oral Dis. 2021, 27, 665-673. [CrossRef] [PubMed]

88. Rehman, Z.U.; Khalid, U. Reuse of COVID-19 face mask for the amelioration of mechanical properties of fat clay: A novel solution to an emerging waste problem. Sci. Total Environ. 2021, 794, 148746. [CrossRef]

89. Asim, N.; Badiei, M.; Sopian, K. Review of the valorization options for the proper disposal of face masks during the COVID-19 pandemic. Environ. Technol. Innov. 2021, 23, 101797. [CrossRef] [PubMed]

90. Battegazzore, D.; Cravero, F.; Frache, A. Is it Possible to Mechanical Recycle the Materials of the Disposable Filtering Masks? Polymer 2020, 12, 2726. [CrossRef]

91. Seresirikachorn, K.; Phoophiboon, V.; Chobarporn, T.; Tiankanon, K.; Aeumjaturapat, S.; Chusakul, S.; Snidvongs, K. Decontamination and reuse of surgical masks and N95 filtering facepiece respirators during the COVID-19 pandemic: A systematic review. Infect. Control Hosp. Epidemiol. 2021, 42, 25-30. [CrossRef]

92. Bergman, M.S.; Viscusi, D.J.; Heimbuch, B.K.; Wander, J.; Sambol, A.R.; Shaffer, R.E. Evaluation of Multiple (3-Cycle) Decontamination Processing for Filtering Facepiece Respirators. J. Eng. Fibers Fabr. 2010, 5, 155892501000500405. [CrossRef]

93. Steinberg, B.E.; Aoyama, K.; McVey, M.; Levin, D.; Siddiqui, A.; Munshey, F.; Goldenberg, N.M.; Faraoni, D.; Maynes, J.T. Efficacy and safety of decontamination for N95 respirator reuse: A systematic literature search and narrative synthesis. Can. J. Anesth. 2020, 67, 1814-1823. [CrossRef]

94. Rowan, N.J.; Laffey, J.G. Unlocking the surge in demand for personal and protective equipment (PPE) and improvised face coverings arising from coronavirus disease (COVID-19) pandemic-Implications for efficacy, re-use and sustainable waste management. Sci. Total Environ. 2021, 752, 142259. [CrossRef]

95. Rodriguez-Martinez, C.E.; Sossa-Briceño, M.P.; Cortes, J. Decontamination and reuse of N95 filtering facemask respirators: A systematic review of the literature. Am. J. Infect. Control 2020, 48, 1520-1532. [CrossRef] [PubMed]

96. Jacobs, N.; Chan, K.; Leso, V.; D’Anna, A.; Hollins, D.; Iavicoli, I. A critical review of methods for decontaminating filtering facepiece respirators. Toxicol. Ind. Health 2020, 36, 654-680. [CrossRef] [PubMed]

97. Cook, T. Personal protective equipment during the coronavirus disease (COVID) 2019 pandemic-A narrative review. Anaesthesia 2020, 75, 920-927. [CrossRef]

98. Hockberger, P.E. A History of Ultraviolet Photobiology for Humans, Animals and Microorganisms. Photochem. Photobiol. 2007, 76, 561-579. [CrossRef]

99. Reed, N.G. The History of Ultraviolet Germicidal Irradiation for Air Disinfection. Public Health Rep. 2010, 125, 15-27. [CrossRef] [PubMed]

100. Downes, A.; Blunt, T. The Influence of Light upon the Development of Bacteria 1. Nature 1877, 16, 218. [CrossRef]

101. EloiseáTorres, A. Ultraviolet-C and other methods of decontamination of filtering facepiece N-95 respirators during the COVID-19 pandemic. Photochem. Photobiol. Sci. 2020.

102. Kowalski, W. UVGI Disinfection Theory. In Ultraviolet Germicidal Irradiation Handbook; Springer: Berlin/Heidelberg, Germany, 2009; pp. 17-50.

103. Raeiszadeh, M.; Adeli, B. A Critical Review on Ultraviolet Disinfection Systems against COVID-19 Outbreak: Applicability, Validation, and Safety Considerations. ACS Photonics 2020, 7, 2941-2951. [CrossRef] 
104. Dusseau, J.Y.; Duroselle, P.; Freney, J. Sterilization: Gaseous Sterilization. In Russell, Hugo E Ayliffe's Principles and Practice of Disinfection, Preservation E Sterilization; Blackwell Publishing Ltd.: Oxford, UK, 2004; pp. 401-435.

105. Blazejewski, C.; Wallet, F.; Rouzé, A.; Le Guern, R.; Ponthieux, S.; Salleron, J.; Nseir, S. Efficiency of hydrogen peroxide in improving disinfection of ICU rooms. Crit Care 2015, 19, 30. [CrossRef] [PubMed]

106. Saini, V.; Sikri, K.; Batra, S.D.; Kalra, P.; Gautam, K. Development of a highly effective low-cost vaporized hydrogen peroxidebased method for disinfection of personal protective equipment for their selective reuse during pandemics. Gut Pathog. 2020, 12, 1-11. [CrossRef]

107. Taheri, S.; Brodie, G.I.; Gupta, D.; Dadu, R.H.R. Effect of Microwave Radiation on Internal Inoculum of Ascochyta Blight in Lentil Seeds at Different Seed Moisture Contents. Trans. ASABE 2019, 62, 33-43. [CrossRef]

108. Shirvanimoghaddam, K.; Czech, B.; Abdikheibari, S.; Brodie, G.; Kończak, M.; Krzyszczak, A.; Al-Othman, A.; Naebe, M. Microwave synthesis of biochar for environmental applications. J. Anal. Appl. Pyrol. 2021, 161, 105415. [CrossRef]

109. Singh, N.; Shrivastava, P.; Shah, M. Microwave-assisted extraction of lemongrass essential oil: Study of the influence of extraction method and process parameters on extraction process. J. Chem. Pharm. Res. 2014, 6, 385-389.

110. Brodie, G. Microwave technique speeds timber processing. Adv. Mater. Process. 2004, 162, 16.

111. Shirvanimoghaddam, K.; Czech, B.; Tyszczuk-Rotko, K.; Kończak, M.; Fakhrhoseini, S.M.; Yadav, R.; Naebe, M. Sustainable synthesis of rose flower-like magnetic biochar from tea waste for environmental applications. J. Adv. Res. 2021, 34, 13-27. [CrossRef]

112. Ghasali, E.; Alizadeh, M.; Shirvanimoghaddam, K.; Mirzajany, R.; Niazmand, M.; Faeghi-Nia, A.; Ebadzadeh, T. Porous and non-porous alumina reinforced magnesium matrix composite through microwave and spark plasma sintering processes. Mater. Chem. Phys. 2018, 212, 252-259. [CrossRef]

113. Nelson, S. Radio-frequency and microwave dielectric properties of insects. J. Microw. Power Electromagn. Energy 2001, 36, 47-56. [CrossRef]

114. Brodie, G. Applications of Microwave Heating in Agricultural and Forestry Related Industries. In The Development and Application of Microwave Heating; Cao, W., Ed.; InTech: Rijeka, Croatia, 2012; pp. 45-78.

115. Zhang, Y.; Hu, J.; Yan, X. Dielectric constants of sewed multilayer fabric for wearable e-textiles. J. Ind. Text. 2020, 1-18. [CrossRef]

116. Wee, F.H.; Soh, P.J.; Suhaizal, A.H.M.; Nornikman, H.; Ezanuddin, A.A.M. Free space measurement technique on dielectric properties of agricultural residues at microwave frequencies. In Proceedings of the Microwave and Optoelectronics Conference (IMOC), 2009 SBMO/IEEE MTT-S International, Belem, Brazil, 3-6 November 2009.

117. Ko, R.S.; Zoerb, G.C. Dielectric Constant of Wheat Straw. Trans. Am. Soc. Agric. Biol. Eng. 1970, 13, 42-45.

118. Brodie, G. Simultaneous Heat and Moisture Diffusion During Microwave Heating of Moist Wood. Appl. Eng. Agric. 2007, 23, 179-187. [CrossRef]

119. Viscusi, D.J.; Bergman, M.S.; Eimer, B.C.; Shaffer, R.E. Evaluation of Five Decontamination Methods for Filtering Facepiece Respirators. Ann. Occup. Hyg. 2009, 53, 815-827. [CrossRef] [PubMed]

120. Lore, M.B.; Heimbuch, B.K.; Brown, T.L.; Wander, J.D.; Hinrichs, S.H. Effectiveness of Three Decontamination Treatments against Influenza Virus Applied to Filtering Facepiece Respirators. Ann. Occup. Hyg. 2011, 56, 92-101. [CrossRef]

121. Siddharta, A.; Pfaender, S.; Malassa, A.; Doerrbecker, J.; Anggakusuma; Engelmann, M.; Nugraha, B.; Steinmann, J.; Todt, D.; Vondran, F.W.R. Inactivation of HCV and HIV by microwave: A novel approach for prevention of virus transmission among people who inject drugs. Sci. Rep. 2016, 6, 36619. [CrossRef]

122. Baranwal, A.; Srivastava, A.; Kumar, P.; Bajpai, V.K.; Maurya, P.K.; Chandra, P. Prospects of Nanostructure Materials and Their Composites as Antimicrobial Agents. Front. Microbiol. 2018, 9, 422. [CrossRef]

123. Binas, V.; Venieri, D.; Kotzias, D.; Kiriakidis, G. Modified $\mathrm{TiO}_{2}$ based photocatalysts for improved air and health quality. $J$. Materiomics 2017, 3, 3-16. [CrossRef]

124. Wang, W.; Huang, G.; Yu, J.; Wong, P.K. Advances in photocatalytic disinfection of bacteria: Development of photocatalysts and mechanisms. J. Environ. Sci. 2015, 34, 232-247. [CrossRef]

125. Li, Y.; Leung, P.; Yao, L.; Song, Q.; Newton, E. Antimicrobial effect of surgical masks coated with nanoparticles. J. Hosp. Infect. 2006, 62, 58-63. [CrossRef]

126. Borkow, G.; Zhou, S.S.; Page, T.; Gabbay, J. A Novel Anti-Influenza Copper Oxide Containing Respiratory Face Mask. PLoS ONE 2010, 5, e11295. [CrossRef]

127. Pini, M.; González, E.I.C.; Neri, P.; Siligardi, C.; Ferrari, A.M. Assessment of Environmental Performance of $\mathrm{TiO}_{2} \mathrm{Nanoparticles}$ Coated Self-Cleaning Float Glass. Coatings 2017, 7, 8. [CrossRef]

128. Hoseinzadeh, E.; Makhdoumi, P.; Taha, P.; Hossini, H.; Stelling, J.; Kamal, M.A.; Ashraf, G.M. A Review on Nano-Antimicrobials: Metal Nanoparticles, Methods and Mechanisms. Curr. Drug Metab. 2017, 18, 120-128. [CrossRef]

129. Slavin, Y.N.; Asnis, J.; Häfeli, U.O.; Bach, H. Metal nanoparticles: Understanding the mechanisms behind antibacterial activity. J. Nanobiotechnol. 2017, 15, 65. [CrossRef]

130. O’Dowd, K.; Nair, K.M.; Forouzandeh, P.; Mathew, S.; Grant, J.; Moran, R.; Bartlett, J.; Bird, J.; Pillai, S.C. Face Masks and Respirators in the Fight against the COVID-19 Pandemic: A Review of Current Materials, Advances and Future Perspectives. Materials 2020, 13, 3363. [CrossRef]

131. Takashi, K.; Akira, K.; Akihiko, Y. Infection Prevention Mask. US Patent 2005124777A, 19 May 2005.

132. Lee, W.X.; Nu, M. Functional Protective Mask. US Patent 201320356118, 18 December 2013. 
133. Hiragond, C.B.; Kshirsagar, A.; Dhapte, V.V.; Khanna, T.; Joshi, P.; More, P.V. Enhanced anti-microbial response of commercial face mask using colloidal silver nanoparticles. Vacuum 2018, 156, 475-482. [CrossRef]

134. Akduman, C.; Akçakoca Kumbasar, E.P. Nanofibers in face masks and respirators to provide better protection. IOP Conf. Ser. Mater. Sci. Eng. 2018, 460, 012013. [CrossRef]

135. Beyth, N.; Houri-Haddad, Y.; Domb, A.; Khan, W.; Hazan, R. Alternative Antimicrobial Approach: Nano-Antimicrobial Materials Evid.-Based Complement. Altern. Med. 2015, 2015, 246012. [CrossRef]

136. Tamayo, L.; Azócar, M.; Kogan, M.; Riveros, A.; Páez, M. Copper-polymer nanocomposites: An excellent and cost-effective biocide for use on antibacterial surfaces. Mater. Sci. Eng. C 2016, 69, 1391-1409. [CrossRef] [PubMed]

137. Chin, A.W.H.; Chu, J.T.S.; Perera, M.R.A.; Hui, K.P.Y.; Yen, H.; Chan, M.C.W.; Peiris, M.; Poon, L.L.M. Stability of SARS-CoV-2 in different environmental conditions. Lancet Microbe 2020, 1, e10. [CrossRef]

138. Musico, Y.L.F.; Santos, C.M.; Dalida, M.L.P.; Rodrigues, D.F. Surface Modification of Membrane Filters Using Graphene and Graphene Oxide-Based Nanomaterials for Bacterial Inactivation and Removal. ACS Sustain. Chem. Eng. 2014, 2, 1559-1565. [CrossRef]

139. Palmieri, V.; Papi, M. Can graphene take part in the fight against COVID-19? Nano Today 2020, 33, 100883. [CrossRef] [PubMed]

140. Zhu, J.; Wang, J.; Hou, J.; Zhang, Y.; Liu, J.; Van der Bruggen, B. Graphene-based antimicrobial polymeric membranes: A review. J. Mater. Chem. A 2017, 5, 6776-6793. [CrossRef]

141. Stanford, M.G.; Li, J.T.; Chen, Y.; McHugh, E.A.; Liopo, A.; Xiao, H.; Tour, J.M. Self-Sterilizing Laser-Induced Graphene Bacterial Air Filter. ACS Nano 2019, 13, 11912-11920. [CrossRef] [PubMed]

142. Jones, S.T.; Cagno, V.; Janeček, M.; Ortiz, D.; Gasilova, N.; Piret, J.; Gasbarri, M.; Constant, D.A.; Han, Y.; Vukovič, L.; et al Modified cyclodextrins as broad-spectrum antivirals. Sci. Adv. 2020, 6, eaax9318. [CrossRef] [PubMed]

143. Naskalska, A.; Dabrowska, A.; Szczepański, A.; Milewska, A.; Jasik, K.P.; Pyrc, K. Membrane Protein of Human Coronavirus NL63 Is Responsible for Interaction with the Adhesion Receptor. J. Virol. 2019, 93, 00355-19. [CrossRef]

144. Turcheniuk, K.; Hage, C.-H.; Spadavecchia, J.; Serrano, A.Y.; Larroulet, I.; Pesquera, A.; Zurutuza, A.; Pisfil, M.G.; Héliot, L.; Boukaert, J.; et al. Plasmonic photothermal destruction of uropathogenic E. coli with reduced graphene oxide and core/shell nanocomposites of gold nanorods/reduced graphene oxide. J. Mater. Chem. B 2015, 3, 375-386. [CrossRef]

145. Hui, L.; Auletta, J.T.; Huang, Z.; Chen, X.; Xia, F.; Yang, S.; Liu, H.; Yang, L. Surface Disinfection Enabled by a Layer-by-Layer Thin Film of Polyelectrolyte-Stabilized Reduced Graphene Oxide upon Solar Near-Infrared Irradiation. ACS Appl. Mater. Interfaces 2015, 7, 10511-10517. [CrossRef]

146. Ziem, B.; Azab, W.; Gholami, M.F.; Rabe, J.P.; Osterrieder, N.; Haag, R. Size-dependent inhibition of herpesvirus cellular entry by polyvalent nanoarchitectures. Nanoscale 2017, 9, 3774-3783. [CrossRef]

147. Chen, Y.-N.; Hsueh, Y.-H.; Hsieh, C.-T.; Tzou, D.-Y.; Chang, H.-T. Antiviral Activity of Graphene-Silver Nanocomposites against Non-Enveloped and Enveloped Viruses. Int. J. Environ. Res. Public Health 2016, 13, 430. [CrossRef]

148. Ziem, B.; Thien, H.; Achazi, K.; Yue, C.; Stern, D.; Silberreis, K.; Gholami, M.F.; Beckert, F.; Gröger, D.; Mülhaupt, R.; et al. Highly Efficient Multivalent 2D Nanosystems for Inhibition of Orthopoxvirus Particles. Adv. Health Mater. 2016, 5, 2922-2930. [CrossRef]

149. Iannazzo, D.; Pistone, A.; Ferro, S.; De Luca, L.; Monforte, A.M.; Romeo, R.; Buemi, M.R.; Pannecouque, C. Graphene Quantum Dots Based Systems as HIV Inhibitors. Bioconjg. Chem. 2018, 29, 3084-3093. [CrossRef]

150. Du, X.; Xiao, R.; Fu, H.; Yuan, Z.; Zhang, W.; Yin, L.; He, C.; Li, C.; Zhou, J.; Liu, G.; et al. Hypericin-loaded graphene oxide protects ducks against a novel duck reovirus. Mater. Sci. Eng. C 2019, 105, 110052. [CrossRef]

151. Steinberg, R.S.; Cruz, M.; Mahfouz, N.G.A.; Qiu, Y.; Hurt, R.H. Breathable Vapor Toxicant Barriers Based on Multilayer Graphene Oxide. ACS Nano 2017, 11, 5670-5679. [CrossRef]

152. Zhong, H.; Zhu, Z.; Lin, J.; Cheung, C.; Lu, V.L.; Yan, F.; Chan, C.-Y.; Li, G. Reusable and Recyclable Graphene Masks with Outstanding Superhydrophobic and Photothermal Performances. ACS Nano 2020, 14, 6213-6221. [CrossRef] [PubMed]

153. Shan, X.; Zhang, H.; Liu, C.; Yu, L.; Di, Y.; Zhang, X.; Dong, L.; Gan, Z. Reusable Self-Sterilization Masks Based on Electrothermal Graphene Filters. ACS Appl. Mater. Interfaces 2020, 12, 56579-56586. [CrossRef]

154. Darnell, M.E.; Subbarao, K.; Feinstone, S.M.; Taylor, D.R. Inactivation of the coronavirus that induces severe acute respiratory syndrome, SARS-CoV. J. Virol. Methods 2004, 121, 85-91. [CrossRef] [PubMed]

155. Lin, Z.; Wang, Z.; Zhang, X.; Diao, D. Superhydrophobic, photo-sterilize, and reusable mask based on graphene nanosheetembedded carbon (GNEC) film. Nano Res. 2021, 14, 1110-1115. [CrossRef]

156. Shen, H.; Leonas, K.K. Study of Repellent Finish of Filtration Ability of Surgical Face Masks. Int. Nonwovens J. 2005, 4, 1558925005os-1400403. [CrossRef]

157. Majchrzycka, K.; Okrasa, M.; Szulc, J.; Jachowicz, A.; Gutarowska, B. Survival of Microorganisms on Nonwovens Used for the Construction of Filtering Facepiece Respirators. Int. J. Environ. Res. Public Health 2019, 16, 1154. [CrossRef]

158. Wu, T.; Li, H.; Xue, J.; Mo, X.; Xia, Y. Photothermal Welding, Melting, and Patterned Expansion of Nonwoven Mats of Polymer Nanofibers for Biomedical and Printing Applications. Angew. Chem. Int. Ed. 2019, 58, 16416-16421. [CrossRef] [PubMed]

159. Fusco, L.; Gazzi, A.; Peng, G.; Shin, Y.; Vranic, S.; Bedognetti, D.; Vitale, F.; Yilmazer, A.; Feng, X.; Fadeel, B.; et al. Graphene and other 2D materials: A multidisciplinary analysis to uncover the hidden potential as cancer theranostics. Theranostics 2020, 10, 5435-5488. [CrossRef] [PubMed]

160. Weiss, C.; Carriere, M.; Fusco, L.; Capua, I.; Regla-Nava, J.A.; Pasquali, M.; Scott, J.A.; Vitale, F.; Unal, M.A.; Mattevi, C.; et al. Toward Nanotechnology-Enabled Approaches against the COVID-19 Pandemic. ACS Nano 2020, 14, 6383-6406. [CrossRef] 
161. Taheri, H.; Unal, M.A.; Sevim, M.; Gurcan, C.; Ekim, O.; Ceylan, A.; Syrgiannis, Z.; Christoforidis, K.C.; Bosi, S.; Ozgenç, O.; et al. Photocatalytically Active Graphitic Carbon Nitride as an Effective and Safe 2D Material for In Vitro and In Vivo Photodynamic Therapy. Small 2020, 16, 1904619. [CrossRef]

162. Abolhasani, M.M.; Naebe, M.; Amiri, M.H.; Shirvanimoghaddam, K.; Anwar, S.; Michels, J.J.; Asadi, K. Hierarchically Structured Porous Piezoelectric Polymer Nanofibers for Energy Harvesting. Adv. Sci. 2020, 7, 2000517. [CrossRef]

163. Abolhasani, M.M.; Naebe, M.; Shirvanimoghaddam, K.; Fashandi, H.; Joordens, H.K.M.; Pipertzis, A.; Anwar, S.; Berger, R.; Floudas, G.; Michels, J.; et al. Thermodynamic approach to tailor porosity in piezoelectric polymer fibers for application in nanogenerators. Nano Energy 2019, 62, 594-600. [CrossRef]

164. Abolhasani, M.M.; Shirvanimoghaddam, K.; Naebe, M. PVDF/graphene composite nanofibers with enhanced piezoelectric performance for development of robust nanogenerators. Compos. Sci. Technol. 2017, 138, 49-56. [CrossRef]

165. Abolhasani, M.M.; Shirvanimoghaddam, K.; Khayyam, H.; Moosavi, S.M.; Zohdi, N.; Naebe, M. Towards predicting the piezoelectricity and physiochemical properties of the electrospun $\mathrm{P}$ (VDF-TrFE) nanogenrators using an artificial neural network Polym. Test. 2018, 66, 178-188. [CrossRef]

166. Ahmadabadi, V.G.; Shirvanimoghaddam, K.; Kerr, R.; Showkath, N.; Naebe, M. Structure-rate performance relationship in Si nanoparticles-carbon nanofiber composite as flexible anode for lithium-ion batteries. Electrochim. Acta 2020, 330, 135232. [CrossRef]

167. Abolhasani, M.M.; Azimi, S.; Mousavi, M.; Anwar, S.; Amiri, M.H.; Shirvanimoghaddam, K.; Naebe, M.; Michels, J.; Asadi, K. Porous graphene/poly(vinylidene fluoride) nanofibers for pressure sensing. J. Appl. Polym. Sci. 2021, 51907. [CrossRef]

168. Gibson, P.; Schreuder-Gibson, H.; Rivin, D. Transport properties of porous membranes based on electrospun nanofibers. Colloids Surf. A Physicochem. Eng. Asp. 2001, 187, 469-481. [CrossRef]

169. Naebe, M.; Lin, T.; Wang, X. Carbon Nanotubes Reinforced Electrospun Polymer Nanofibres. Intech Open, 2010, 309-328. [CrossRef]

170. Baqeri, M.; Abolhasani, M.M.; Mozdianfard, M.R.; Guo, Q.; Oroumei, A.; Naebe, M. Influence of processing conditions on polymorphic behavior, crystallinity, and morphology of electrospun poly(VInylidene fluoride) nanofibers. J. Appl. Polym. Sci. 2015, 132. [CrossRef]

171. Zhang, Z.; Ji, D.; He, H.; Ramakrishna, S. Electrospun ultrafine fibers for advanced face masks. Mater. Sci. Eng. R Rep. 2021, 143, 100594. [CrossRef] [PubMed]

172. Shafei, S.; Foroughi, J.; Stevens, L.; Wong, C.S.; Zabihi, O.; Naebe, M. Electroactive nanostructured scaffold produced by controlled deposition of PPy on electrospun PCL fibres. Res. Chem. Intermed. 2017, 43, 1235-1251. [CrossRef]

173. Rostami, M.; Ghorbani, M.; Mohammadi, M.A.; Delavar, M.; Tabibiazar, M.; Ramezani, S. Development of resveratrol loaded chitosan-gellan nanofiber as a novel gastrointestinal delivery system. Int. J. Biol. Macromol. 2019, 135, 698-705. [CrossRef] [PubMed]

174. Chang, C.-Y.; Chang, F.-C. Development of Electrospun Lignin-based Fibrous Materials for Filtration Applications. BioResources 2016, 2016, 2202-2213. [CrossRef]

175. Raza, Z.A.; Khalil, S.; Ayub, A.; Banat, I.M. Recent developments in chitosan encapsulation of various active ingredients for multifunctional applications. Carbohydr. Res. 2020, 492, 108004. [CrossRef]

176. Kutzli, I.; Gibis, M.; Baier, S.K.; Weiss, J. Electrospinning of whey and soy protein mixed with maltodextrin-Influence of protein type and ratio on the production and morphology of fibers. Food Hydrocoll. 2019, 93, 206-214. [CrossRef]

177. Jung, Y.; Yang, H.; Lee, I.-Y.; Yong, T.-S.; Lee, S. Core/Sheath-Structured Composite Nanofibers Containing Cinnamon Oil: Their Antibacterial and Antifungal Properties and Acaricidal Effect against House Dust Mites. Polymer 2020, 12, 243. [CrossRef]

178. Lancuški, A.; Abu Ammar, A.; Avrahami, R.; Vilensky, R.; Vasilyev, G.; Zussman, E. Design of starch-formate compound fibers as encapsulation platform for biotherapeutics. Carbohydr. Polym. 2017, 158, 68-76. [CrossRef] [PubMed]

179. Gore, P.; Naebe, M.; Wang, X.; Kandasubramanian, B. Progress in silk materials for integrated water treatments: Fabrication, modification and applications. Chem. Eng. J. 2019, 374, 437-470. [CrossRef]

180. Gore, P.; Naebe, M.; Wang, X.; Kandasubramanian, B. Silk fibres exhibiting biodegradability \& superhydrophobicity for recovery of petroleum oils from oily wastewater. J. Hazard. Mater. 2020, 389, 121823. [CrossRef] [PubMed]

181. Chen, J.-W.; Lee, G.W.-M.; Chen, K.-J.; Yang, S.-H. Control of Bioaerosols in Indoor Environment by Filter Coated with Nanosilicate Platelet Supported Silver Nanohybrid (AgNPs/NSP). Aerosol Air Qual. Res. 2016, 16, 2198-2207. [CrossRef]

182. Zhong, Z.X.; Xu, Z.; Sheng, T.; Yao, J.F.; Xing, W.H.; Wang, Y. Unusual Air Filters with Ultrahigh Efficiency and Antibacterial Functionality Enabled by ZnO Nanorods. ACS Appl. Mater. Interfaces 2015, 7, 21538-21544. [CrossRef]

183. Choi, D.Y.; Heo, K.J.; Kang, J.; An, E.J.; Jung, S.-H.; Lee, B.U.; Lee, H.M.; Jung, J.H. Washable antimicrobial polyester/aluminum air filter with a high capture efficiency and low pressure drop. J. Hazard. Mater. 2018, 351, 29-37. [CrossRef]

184. Feng, S.; Li, D.; Low, Z.-X.; Liu, Z.; Zhong, Z.; Hu, Y.; Wang, Y.; Xing, W. ALD-seeded hydrothermally-grown Ag/ZnO nanorod PTFE membrane as efficient indoor air filter. J. Membr. Sci. 2017, 531, 86-93. [CrossRef]

185. Chuaybamroong, P.; Chotigawin, R.; Supothina, S.; Sribenjalux, P.; Larpkiattaworn, S.; Wu, C.-Y. Efficacy of photocatalytic HEPA filter on microorganism removal. Indoor Air 2010, 20, 246-254. [CrossRef]

186. Wang, Z.; Pan, Z.; Wang, J.; Zhao, R. A novel hierarchical structured poly (lactic acid)/titania fibrous membrane with excellent antibacterial activity and air filtration performance. J. Nanomater. 2016, 2016, 39. [CrossRef] 
187. Jung, J.H.; Hwang, G.B.; Lee, J.E.; Bae, G.N. Preparation of Airborne Ag/CNT Hybrid Nanoparticles Using an Aerosol Process and Their Application to Antimicrobial Air Filtration. Langmuir 2011, 27, 10256-10264. [CrossRef]

188. Pei, L.; Zhou, J.; Zhang, L. Preparation and properties of Ag-coated activated carbon nanocomposites for indoor air quality control. Build. Environ. 2013, 63, 108-113. [CrossRef]

189. Zhao, Y.; Low, Z.-X.; Feng, S.; Zhong, Z.; Wang, Y.; Yao, Z. Multifunctional hybrid porous filters with hierarchical structures for simultaneous removal of indoor VOCs, dusts and microorganisms. Nanoscale 2017, 9, 5433-5444. [CrossRef]

190. Shirvanimoghaddam, K.; Abolhasani, M.M.; Li, Q.; Khayyam, H.; Naebe, M. Cheetah skin structure: A new approach for carbon-nano-patterning of carbon nanotubes. Compos. Part A Appl. Sci. Manuf. 2017, 95, 304-314. [CrossRef]

191. Shirvanimoghaddam, K.; Motamed, B.; Ramakrishna, S.; Naebe, M. Death by waste: Fashion and textile circular economy case. Sci. Total Environ. 2020, 718, 137317. [CrossRef] [PubMed]

192. Czech, B.; Shirvanimoghaddam, K.; Trojanowska, E.; Naebe, M. Sorption of pharmaceuticals and personal care products (PPCPs) onto a sustainable cotton based adsorbent. Sustain. Chem. Pharm. 2020, 18, 100324. [CrossRef]

193. Fakhrhoseini, S.M.; Czech, B.; Shirvanimoghaddam, K.; Naebe, M. Ultrafast microwave assisted development of magnetic carbon microtube from cotton waste for wastewater treatment. Colloids Surf. A Physicochem. Eng. Asp. 2020, 606, 125449. [CrossRef]

194. Shirvanimoghaddam, K.; Czech, B.; Wójcik, G.; Naebe, M. The light enhanced removal of Bisphenol A from wastewater using cotton waste derived carbon microtubes. J. Colloid Interface Sci. 2019, 539, 425-432. [CrossRef]

195. Shirvanimoghaddam, K.; Czech, B.; Wiącek, A.E.; Ćwikła-Bundyra, W.; Naebe, M. Sustainable carbon microtube derived from cotton waste for environmental applications. Chem. Eng. J. 2019, 361, 1605-1616. [CrossRef]

196. Chowdhury, M.A.; Shuvho, B.A.; Shahid, A.; Haque, A.M.; Kashem, M.A.; Lam, S.S.; Ong, H.C.; Uddin, A.; Mofijur, M. Prospect of biobased antiviral face mask to limit the coronavirus outbreak. Environ. Res. 2021, 192, 110294. [CrossRef]

197. Rahman, K.U.; Ferreira-Neto, E.P.; Rahman, G.U.; Parveen, R.; Monteiro, A.S.; Rahman, G.; Van Le, Q.; Domeneguetti, R.R.; Ribeiro, S.J.; Ullah, S. Flexible bacterial cellulose-based $\mathrm{BC}-\mathrm{SiO}_{2}-\mathrm{TiO}_{2}-\mathrm{Ag}$ membranes with self-cleaning, photocatalytic, antibacterial and UV-shielding properties as a potential multifunctional material for combating infections and environmental applications. J. Environ. Chem. Eng. 2021, 9, 104708. [CrossRef]

198. Hao, Z.; Wu, J.; Wang, C.; Liu, J. Electrospun Polyimide/Metal-Organic Framework Nanofibrous Membrane with Superior Thermal Stability for Efficient PM2.5 Capture. ACS Appl. Mater. Interfaces 2019, 11, 11904-11909. [CrossRef] [PubMed]

199. Unnikrishnan, V.; Zabihi, O.; Ahmadi, M.; Li, Q.; Blanchard, P.; Kiziltas, A.; Naebe, M. Metal-organic framework structureproperty relationships for high-performance multifunctional polymer nanocomposite applications. J. Mater. Chem. A 2021, 9 , 4348-4378. [CrossRef]

200. Ghatak, B.; Banerjee, S.; Ali, S.B.; Bandyopadhyay, R.; Das, N.; Mandal, D.; Tudu, B. Design of a self-powered triboelectric face mask. Nano Energy 2021, 79, 105387. [CrossRef] [PubMed]

201. Sun, Z.; Ostrikov, K.K. Future antiviral surfaces: Lessons from COVID-19 pandemic. Sustain. Mater. Technol. 2020, 25, e00203. [CrossRef]

202. Stephens, B.; Azimi, P.; Thoemmes, M.S.; Heidarinejad, M.; Allen, J.G.; Gilbert, J.A. Microbial Exchange via Fomites and Implications for Human Health. Curr. Pollut. Rep. 2019, 5, 198-213. [CrossRef] [PubMed]

203. Thurman, R.B.; Gerba, C.P.; Bitton, G. The molecular mechanisms of copper and silver ion disinfection of bacteria and viruses Crit. Rev. Environ. Control 1989, 18, 295-315. [CrossRef]

204. Sunada, K.; Minoshima, M.; Hashimoto, K. Highly efficient antiviral and antibacterial activities of solid-state cuprous compounds. J. Hazard. Mater. 2012, 235, 265-270. [CrossRef] [PubMed]

205. Kilmartin-Lynch, S.; Saberian, M.; Li, J.; Roychand, R.; Zhang, G. Preliminary evaluation of the feasibility of using polypropylene fibres from COVID-19 single-use face masks to improve the mechanical properties of concrete. J. Clean. Prod. 2021, 296, 126460. [CrossRef]

206. Rehman, Z.U.; Khalid, U. Optimization of COVID-19 face mask waste fibers and silica fume as a balanced mechanical ameliorator of fat clay using response surface methodology. Environ. Sci. Pollut. Res. 2021, 1-16. [CrossRef] [PubMed]

207. Mwema, F.; Nyika, J. Challenges in facemasks use and potential solutions: The case study of Kenya. Sci. Afr. 2020,10, e00563. [CrossRef] 